\title{
北上低地帯における河成段丘面の編年および 後期更新世における岩首供給1)
}

\author{
渡辺満 久 ${ }^{2)}$

\section{Chronology of the Fluvial Terrace Surfaces in the Kitakami Lowland, Northeast Japan, and Fluctuations of Debris Supply during the Late Pleistocene ${ }^{1)}$}

\author{
Mitsuhisa WATANABE ${ }^{2)}$
}

The Ou Range, the backbone of Northeast Japan which is less than 1,000 $\mathrm{m}$ high except for sporadic Quaternary volcanoes and some peaks, has shed debris eastward into the Kitakami Lowland during the Quaternary. This paper, after establishing the classification and correlation of the fluvial terrace surfaces in the Kitakami Lowland in stratigraphic relation with a number of marker tephras, discusses fluctuations of debris supply during the Late Pleistocene in eastern Japan.

The fluvial surfaces in the Kitakami Lowland are divided into the $\mathrm{Tl} \sim \mathrm{T} 3, \mathrm{H} 1 \sim \mathrm{H} 2$, $\mathrm{M} 1 \sim \mathrm{M} 2$ and $\mathrm{L} 1 \sim \mathrm{L} 2$ surfaces, in descending order. T1 $\sim \mathrm{T} 3$ surfaces are accumulation surfaces that had developed during the Middle Pleistocene. The $\mathrm{H} 1 \sim \mathrm{H} 2$ surfaces are correlated to the penultimate glacial in age. The Ml surface is a distinct depositional surface, and was formed in the period of stage 5 of oxygen isotope record before 90 (80) ka. The M2 and L1 surfaces were built up in the early stadial (approx. 60 40ka) and the later stadial (around 20ka) of the Last Glacial, respectively. The L1 surface is an accumulation surface. However, there is no evidence of remarkable deposition associated with the M2 surface. The L2 surface is dated at several ka.

Two characteristic features on debris-supply fluctuations during the late Pleistocene can be pointed out as follows : 1) a distinct accumulation period in stage 5 and in the later stadial, 2) very small debris accumulation in the early stadial. A swell in supplied debris indicate that the forest-line of the Ou Range dropped and that expansion of debrissupply area in the range occurred. Thus, the biggest drop in forest-line altitude occurred in stage 5 and/or in the later stadial. The area above the forest-line had scarcely developed around the Ou range in the early stadial.

A comparison of landform evolution around the Ou Range to that aroud a mountainous area that has been high in altitude or in latitude, such as the Hidaka Range (Hokkaido) or the Japan Alps (Central Japan), enables us to infer the morphogenetic environments during the late Pleistocene in eastern Japan as follows : 1) in stage 5 and the later stadial, the vegetation zone had so lowered that a large amount of debris was supplied during each period in almost all the mountains in eastern Japan ; 2) in the early stadial, a comparatively large area had been beyond the forest-line in the Hidaka Range and the Japan Alps, but a very small area had been beyond it in the other mountains ; 3) because the early stadial was a long cold period, a large amount of debris could be accumulated in the high mountains, in spite of a rather low rate of supply.

1） 1990 年 8 月 21 日受付. 1990 年 12 月 22 日受理. 1990 年度日本地理学会春季学術大会において口頭発表.

2）日本学術振興会特別研究員 (東京大学) JSPS Fellowships for Japanese Junior Scientists, the University of Tokyo. 
A vertical change of vegetation zone to a lower altitude, resulting in an abundant supply of debris, is closely related to cooling. From the point of view of temperature, it is concluded that it had been warmer during the early stadial than during the later stadial. The accumulation period in stage 5 should correspond to cold substages (substage $5 \mathrm{~d}$ and/or $5 b$ ). Although it might have been very cold during substage $5 \mathrm{~d}$ and/or $5 \mathrm{~b}$, the sea level had still been high. Thus, it seems very likely that these periods in stage 5 were characterized by heavy snowfall and the largest glacial extension in the Japanese mountains.

\section{I. は じめに}

日本における河成段丘の形成要因については古くから 議論されてきたが, 気候変化・海面変化との関係が明ら かにされたのは，1960 年代に入ってからであろう.す なわち, 木兽川（吉川, 1961）や相模川（貝塚, 1969) において, 氷期 間水期の河床縦断形や河成段丘の形成 様式の違いが示され, 気候変化・海面変化が段丘形成に 関わる普遍的な要因であることが明らかにされた，その 後, 十勝平野 (平川・小野, 1974), 関東平野 (米澤, 1981 ; 柳田ほか，1982 など）などにおいても同様の地 形発達史が編まれてきた。これらは, 水期には河川上流 部においては堆積が, 下流部では浸蝕が起こり, 逆に間 水期には上流部において浸蝕が, 下流部では堆積が起こ るという，DURY（1959）の提示したモデルを実証する ものでもあった。

近年, 広域テフラの発見を含むテフロクロノロジーの 発展により, 河成段丘の形成年代に関する情報は質量と もに増加した。このような背景の中で, とくに十勝平野 (平川・小野, 1974 ; 小野・平川, 1975), 関東平野周辺 (吉永・宮寺, 1986 など), 日本アルプス (町田・新井, 1979 ; 伊藤， 1983 ; 伊藤・正木，1984，1987など）に おいて,さらに詳細な地形発達史が解き明かされてき た。

最近十数万年間の河川の上・中流部における河成段 丘形成に関していえば，これまでの研究成果は以下の (1)〜（4）のように総括することができるであろう.

(1) 最終間水期極相期（約 $125 \mathrm{ka}$ : 酸素同位体曲線 の substage $5 \mathrm{e}$ ）以降に少なくとも 2 回の岩屃供給の増 大期があった.

（2）そのうち最も明瞭なものは, 約 $50 \mathrm{ka}$ 前後を中 心とするいわゆる最終水期前半と約 $20 \mathrm{ka}$ 前後の最終水 期後半の 2 回の覀水期に対応し, 水河あるいは周水河 的環境の拡大に伴う顕著な岩届供給によって河谷の埋積 が進行して河床が上昇した.

（3）最終水期の前半と後半を比較すると, 河谷の埋 積や山麓部への岩屑供給は前半の方が顕著であった。
（4）业間水期あるいは後水期には，河川は下刻に転 じ，顕著な堆積段丘面・扇状地面が離水した。

このように,いくつかの地域に扔いて，かなり詳しい 地形発達史が明らかにされたことによって，逆に地形形 成に関与した過去の気候条件なども検討することが可能 となった，たとえば，小野・平川（1975）は，氷河の消 長に関する資料などとともに，段丘から得られる情報を もとに, 日高山脈周辺では最終水期の前半と後半とで は, 後半の方がより乾燥・寒冷であったと推定してい る. 河成段丘面の編年，およびこれに基づく地形形成環 境の復元に関しては, その後の研究はこの日高山脈の研 究成果をほぼ支持していると見てよいであろう。

しかしながら, 上述の発達史を, 日本全域あるいは北 海道から日本アルプスにかけての河川の上・中流部にお いて共通する特徵であるとみなすには，いくつかの問題 点を指摘することができる。

第 1 に，日高山脈や日本アルプスなどを除くと，河 成段丘面の確実な編年が行われている地域はほとんどな い.たとえば，両山岳地带の間に位置する東北地力にも 扇状地性の河成段丘面が発達する地域は少なくないが, それらの編年は十分に行われているとは言い難い. 最 近，放射年代測定結果やテフロクロノロジーに基づき， 東北日本各地の $20 \mathrm{ka}$ 前後以降の河川の挙動が解明され つつある(たとえば, TOYoshima，1986).しかし，こ れより古い時代の河成段丘面の編年に関する研究は, 鬼 首カルデラ内（八木・早田，1987）や朝日山地周辺（山 中・八木，1987）の研究以外にはほとんどない.

また, 日射量の変化 (BlatTER et al., 1984) や深海 底コアの酸素同位体比の変化曲線 (SHACKLETON and OPDYKE，1973，1976）から，100 ka 前後に 2 回の比 較的明瞭な寒冷期（substage $5 \mathrm{~d} \cdot 5 \mathrm{~b}$ ) を想定するこ とができる. 海成段丘の解析から求めた海面変動曲線 (CHAPPELL, 1974) にも, この時期に海面が急激に低 下したことをうかがわせる変化が認められる．伊藤 (1983), 伊藤・正木 (1984) は, 日本アルプスにおいて $100 \mathrm{ka}$ 前後に岩屑供給の増大期があると報告してお り, MACHIDA (1980) は日本アルプスの堆積段斥の形 


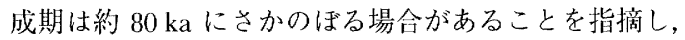
ONO（1983）は約 $80 \mathrm{ka}$ に離水した河成段丘面が分布す ることを図示している.したがって，100 ka 前後にも 比較的明瞭な岩屑供給の増大期があった可能性がきわめ て高い.しかし，この時期における段丘形成に関する情 報はさらに乏しい.これが第 2 の問題点である.

このように，これまでの研究では，扱われている地域 が緯度あるいは高度的に高い日高山脈や日本アルプスの 周辺に限られており，100 ka 前後の段斥形成に関する 資料が十分に揃ってはいない，そのために，50 ka 前後 の最も顕著な段丘形成期とそれに引き続く $20 \mathrm{ka}$ 前後の 段斥形成期といった発達史が普遍的なものであるのか, あるいは最終間水期極相期（substage $5 \mathrm{e}$ ）以降の地形 形成環境の変遷をこれら2回の堆積段丘形成期で代表 して良いのか等, 明確にすべき問題が残されていると考 える.

本研究では, 東北日本の火山フロント沿いに位置する 北上低地帯を調查地域とし, 河成段丘面の対比・編年を 行う. 本地域には, 多数の扇状地性の河成段丘面が発達 し, 多くの示標テフラも認められる. したがって, 本地 域の河成段丘面を編年することによって，北海道と日本 アルプスとの間の空白域を埋めると同時に，約 $100 \mathrm{ka}$ 前後の堆積段庁形成の有無も検討でき，上記の問題にも 迫ることができると考えられる。

北上低地带およびその周辺地域においては，従来から 河成段差およびテフラに関する多数の研究が行われてき た。しかしながら，低地帯全域にわたる河成段丘面の対 比，段丘面の編年に関しては未解決のまま残されている 点が多い. とくに, 最終間水期極相期 最終水期に形成 されたと考えられる段丘面の離水時期に関する知見が不 足している。 その主たる理由は, Aso-4 や Toya といっ た広域テフラと河成段丘面との層位関係が不明のまま残 されていた点にある。

そこで，まず北上低地带南部に㧍ける Aso-4, Toya などの広域火山灰の層準を明らかにし，河成段丘面と各 示標テフラとの関係を示す。次に，北上低地帯の河成段 丘面の対比をより正確にした上で，それらの編年を行 い, 最終間水期極相期（substage $5 \mathrm{e}$ ）以降の岩俩供給 量の変遷について検討を加える.

\section{II. 地形の概観と段丘・テフラに関する従来 の研究}

北上低地帯はその西縁を逆断層に限られた変動性の低 地である (Fig. 1). 同低地带内全域にわたって数段の河 成段压面が発達する。これらの河成段厅面のほとんど
は，低地带西方の奥羽山脈から北上川に流入する諸河川 が形成した扇状地性の河成段丘面である。奥羽山脈は， 火山を除けば，その高度はほぼ $1,000 \mathrm{~m}$ 以下であり， 日本アルプスと比較するとかなり低い山地である。

本低地带に分布する河成段丘面は, 古くから, 地形 発達史を論ずる立場から（東木，1929；田山・土田， 1939 ; 村田, 1939 ; 若生, 1956; 水野, 1960; 中川ほ か, $1963 \mathrm{a}, \mathrm{b}$; 斉藤, 1978), あるいは地款変動を明ら かにする立場から（FUJIWARA，1959；窝城，1975； NAKATA，1976), 研究の対象とされてきた。これらの 研究を通じて, 河成段丘面の区分・対比についてはほほ 同様の結論が得られている. なお, 河成段丘面の発達 程度は南部ほど良好である（中川ほか，1963a，b）た め, その対比・編年を行う上では, 北上低地带の南部 (とくに胆沢台地周辺) が模式地域となる.

段丘面構成層の基盤は新第三系の堆積嵓類および火山 岩類からなる。これらの基盤岩類は, 南部ほど浅い位置 に認められる。北上低地带の中部あるいは北部では, 沈 降運動が卓越してきたために基盤岩類は地下深部に存在 し, 低地带を埋積する未固結で粗粒な堆積層の厚さは最 大で $200 \mathrm{~m}$ 以上に達する（渡辺，1989）.

北上低地帯の北部抢よび南部西方の奥羽山脈上には岩 手川・焼不岳などの第四紀火山が分布する。このため, 本低地帯には，その中部を除けば，比較的厚い第四紀 テフラ層が堆積している。これらのテフラ層序の骨子 は中川ほか（1963 a, b) によって明らかにされこれ これ 以降テフロクロノロジーに基づく段丘面区分がなされ てきた、示標テフラ単位の詳細な記載は, 大上・土井 （1978），大上ほか（1980）および大上・吉田（1984）に よって行われている，北上低地帯のテフラ層序はこれら の研究によってほほ確立された，Aso-4 や Toya などの 広域火山灰の層準については, 町田ほか (1985, 1987) あるいは八木・早田（1989）の研究がある.しかし，こ れら広域テフラと河成段丘面との層位関係はほとんど扱 われてこなかった.

\section{III. 示標テフラと段丘面の記載}

テフラの記載においては, 河成段丘面の編年に関わる 示標テフラを単層単位に示す。 また, 胆沢台地周辺にお いて新たに見いだされた湟汰良好な 6 枚の細粒ガラス 質火山灰と後述の A O P 以外のものについては, 大上. 土井（1978）抢よび大上・吉田（1984）による詳細な報 告があり，筆者の調查によっても若干の追記事項しかな い.このため, それらの示標テフラについてはその概略 を述べるにとどめる，なお，示標テフラの名称について 


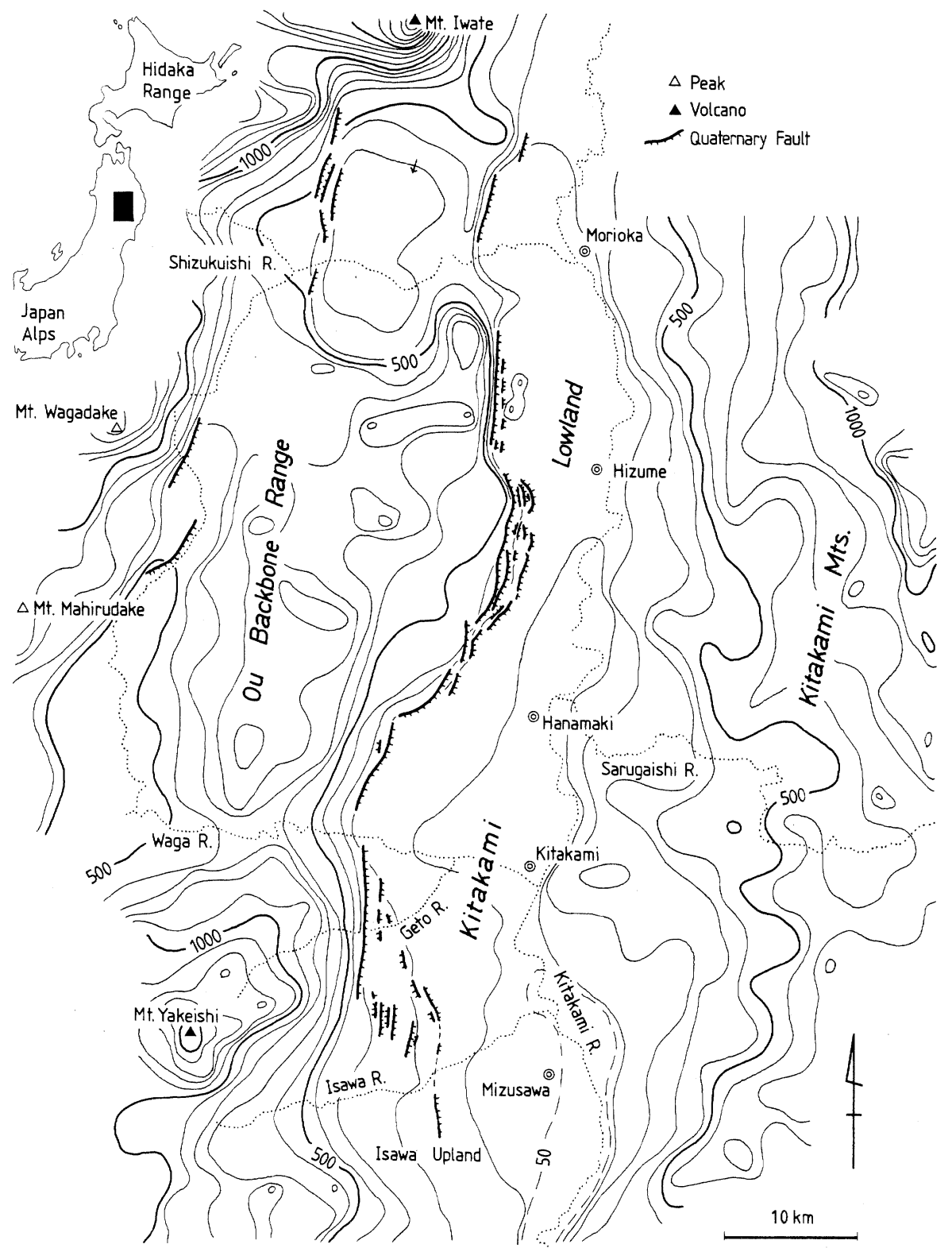

Fig. 1 Topography of the Kitakami Lowland and its environs

は, 中川ほか（1963 a, b)，大上・土井（1978）および 大上・吉田（1984）などにしたがう.

\section{1. 岩手山東麓の示標テフラ}

盛岡の北方, 岩手山東麓においては, Aso-4 は KwP と Is $1 \mathrm{~S}$ との間に, Toya は Is $1 \mathrm{~S}$ と Is $2 \mathrm{~S}$ の間に見い だされる (Fig. 2-a). 岩手山東麓には多数の示標テフラ が認められるが, それらのほとんどは盛岡より南には分
布しない。 また, 古い河成段丘面の発達も悪く, 盛岡以 南に分布する段丘面の編年に利用できる示標テフラは小 岩井浮石（KP）のみである.

\section{小岩井浮石 $(\mathbf{K P})$}

$\mathrm{KP}$ は, 赤橙色の浮石と青灰色のスコリア・岩片, お よび火山砂の互層からなる，厚さは盛岡市付近で $20 \mathrm{~cm}$ 程度であり, 需石川の南方約 $6 \mathrm{~km}$ が分布の南限であ 

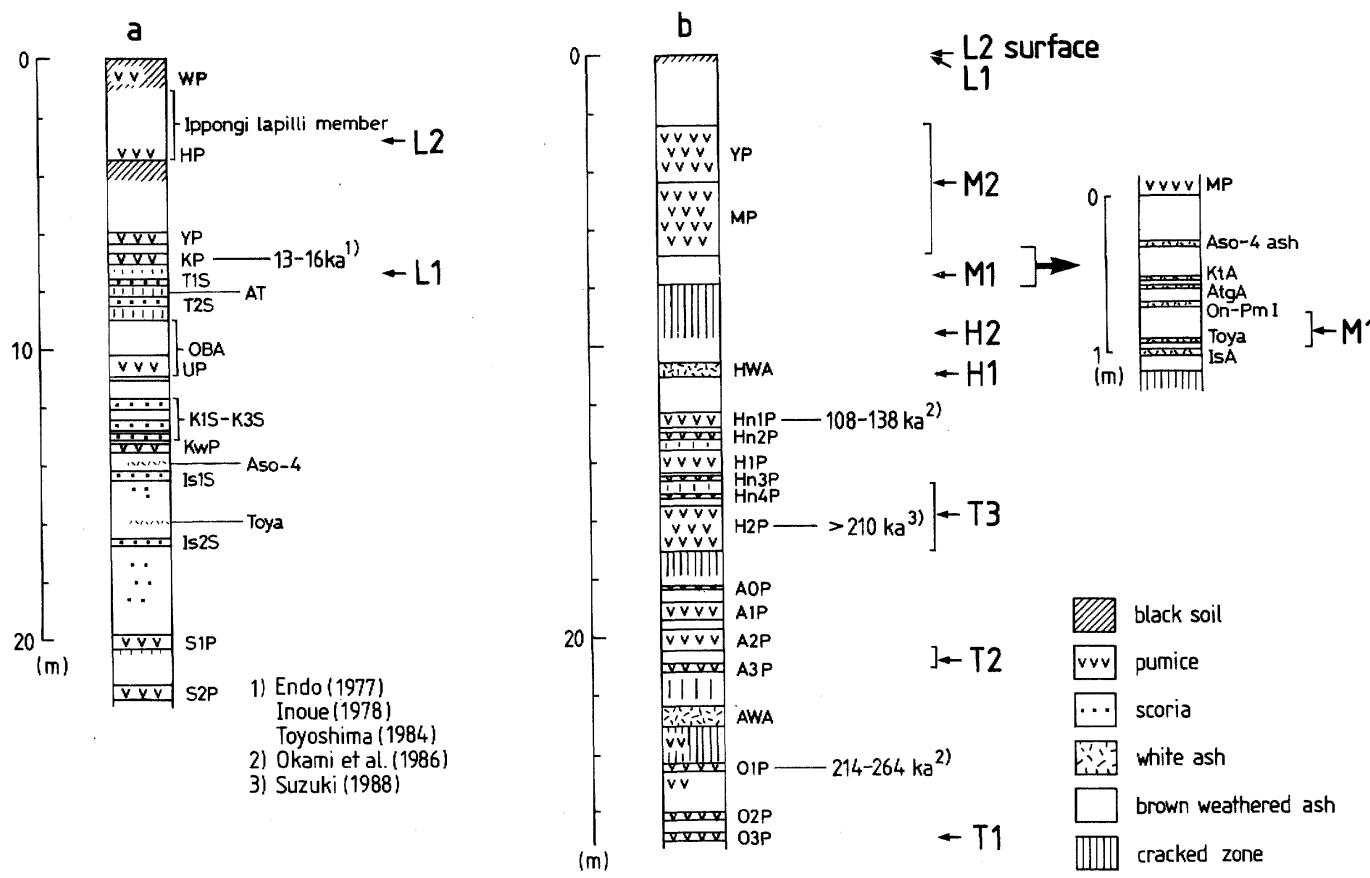

Fig. 2 Standard stratigraphy of tephra and chronology of fluvial terrace surfaces in the Kitakami Lowland a : northern part of the lowland (eastern foot of Iwate Volcano)

b : southern part of the lowland (Isawa Upland)

For the name of the marker tephras, see OKAMI and DOI (1978), OKAMI and YOSHIDA (1984).

る. 本浮石は, 最下部が黒〜青灰色の火山砂からなるこ とから，容易に識別できる。この火山砂の部分の層厚は 盛岡市付近で $5 \mathrm{~cm}$ 程度である. KP の噴出年代につい ては，13〜16 ka とされている $\left({ }^{14} \mathrm{C}\right.$ 年代 : 遠藤， 1977 ; 井上, 1978 ; 豊島, $1984 \mathrm{a})$.

KP の上位には黄白色の柳沢浮石（YP）が堆積し, さらに上方の黑色腐植土壇中には赤褐色の堀切浮石 （HP）が恋められる. なお, HP のさらに上に白色の浮 石が堆積していることを確認した（Fig. 2-a の WP) が，その供給源・分布範讲は不明である.

\section{2. 焼石岳東麓・胆沢台地周辺の示標テフラ}

胆沢台地周辺に厚く分布するテフラ層には, 数 $\mathrm{mm}$ 大でかつ多量の高温型石英が含まれることが多い. 本地 域においては河成段丘面の発達が良好であり, 多数の示 標テフラとの層序関係が確認できる。このため, すべて の示標テフラを下位のものから記載する. 本地域のテフ ラ模式柱状図は Fig. 2-b に示す。今回新たに記載する 細粒ガラス質火山扊の同定は, 野外における層相の観察 や顕微鏡下での特徴に加え, 火山ガラスの主成分化学組 成や屈折率の測定によって行ったそそれらの結果につい
ては，町田ほか (1984) と奥村（1988）のカタログと の比較も行った. 化学分析には東京大学海洋研究所の JCXA-733を, 屈折率の測定には日本大学文理学部応 用地学教室の RIMS 86 を用いた. 火山ガラスの主成分 化学組成と屈折率は Fig. 3 に, 化学組成の数值は補遺 に示した。

\section{大歩第 3〜第 1 軽石 $(\mathbf{O} 3 \mathbf{P} \sim O \mathbf{O}$ )}

各軽石および軽石間の褐色火山兏は，ともに風化が著 しく, 現在のところ胆沢川北岸の Loc. 1 とその周辺に おいてのみ確認できる. O $3 \mathrm{P} \cdot \mathrm{O} 2 \mathrm{P}$ は褐色一肌色を 呈し, 粘土化が著しい. O $1 \mathrm{P}$ は石質岩片に富み, 上部 は灰色，下部は肌色を呈する．本軽石中の黑曜石からは $239 \pm 24.6 \mathrm{ka}$ のフィッショントラック年代測定值が得ら れている(大上ほか，1986）。なお，O１Ｐの上の層準 には風化の進んだ軽石が散在する.

荒屋敷白色細粒火山灰（AWA）, 荒屋敷第 3～第 1 軽石 (A 3 P $\sim$ A 1 P )

AWA は石質岩片を多量に含み，上部は淡褐色，下部 は白色を呈する，粘土化はかなり進んでいる．AWA と $\mathrm{O} 1 \mathrm{P}$ との間には, 厚さ $1 \mathrm{~m}$ 以上の顕著な赤色風化带 


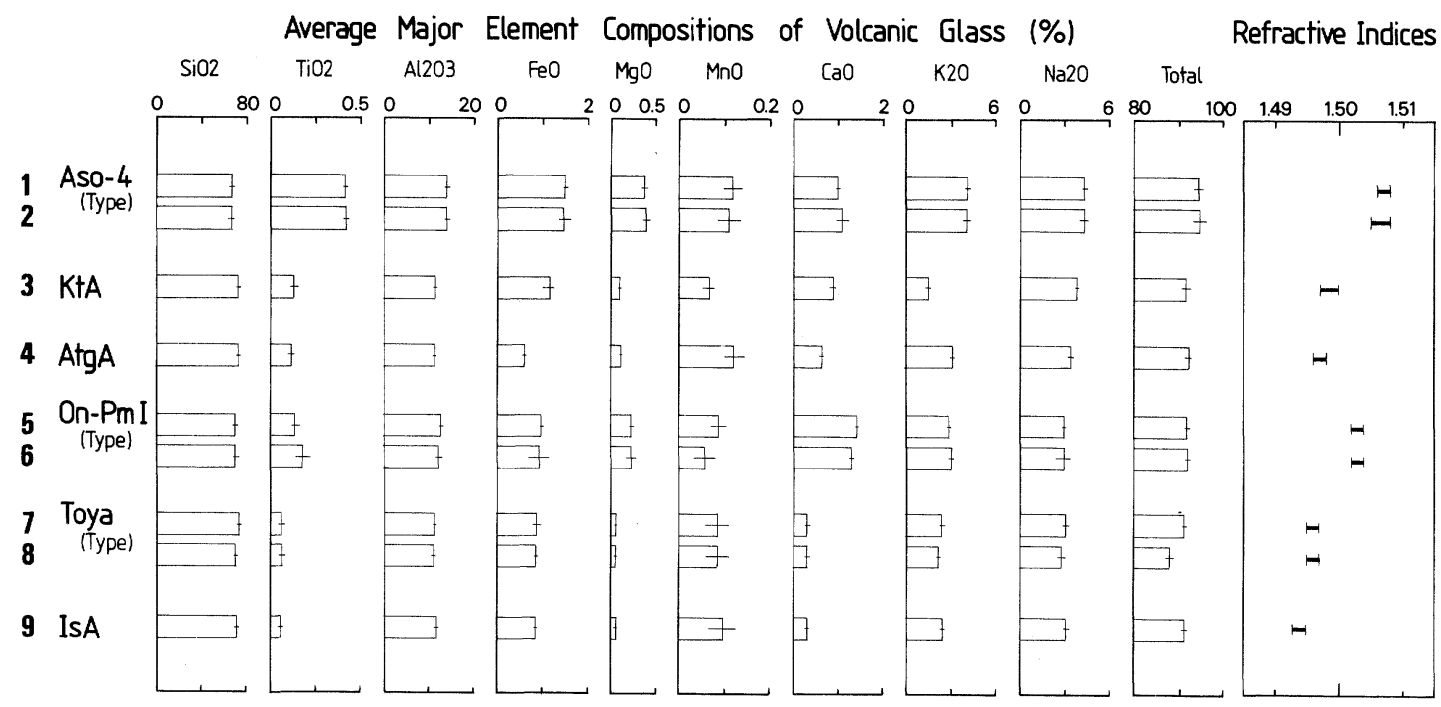

Fig. 3 Average major element compositions and refractive indices of volcanic glass

Sampling localities : 1. Loc. 5b of MACHIDA et al. (1985), 5. Ina Basin, Cantral Japan, 7. Loc. 4g of MACHIDA et al. (1987), others : Locs. 5 and 15 (see Figs. 4 and 5)

が認められる. A 3 P A 1 P は, いずれも橙褐色〜肌色 を呈し, 粘土化が進んでいる. A 3 P の上部は石質岩片 に富む. A 3 P は胆沢台地東部には分布しないが, A 2 P と A 1 P は南方で厚くなる. A 2 P と A 1 P は類似する が, 後者の方が色調は明るい.

\section{荒屋敷第 0 軽石 (A O P : 新称)}

A $1 \mathrm{P}$ の上方約 $20 \mathrm{~cm}$ の位置に, かなり風化した黄 白色～褐色の軽石が点在する.これを荒屋敷第 0 軽石

(A 0 P) と呼ぶ. A 0 P の最下部付近には, 細粒の石質 岩片に富む緑灰色砂状の火山灰も認められ，上部には灰 色の細粒火山灰を伴う。層厚は胆沢台地東部では 5 $\mathrm{cm}$, 胆沢川北岸では $2 \mathrm{~cm}$ 程度である. A $0 \mathrm{P}$ から AWA にかけては, その上下の示標テフラと比較して, 含まれる高温型石英は少量である。なお， A $0 \mathrm{P}$ と後述 の $\mathrm{H} 2 \mathrm{P}$ との間には, 厚さ $1 \mathrm{~m}$ 程度の著しい風化带が 発達している.

萩森第 2, 第 1 軽石 (H 2 P, H 1 P), 日向第 4 第 1 軽石（Hn 4 P Hn 1 P ），萩森白色細粒火山灰 (HWA)

$\mathrm{H} 2 \mathrm{P}$ は明橙褐色〜肌色を呈し, 層厚は最大 $2 \mathrm{~m} に$ 達する。石質岩片の量は少なく，ほほ中央部にガラス。 細粒軽石からなる部分があることから，上い鍵層とな る。このような層相を示す軽石層は, 北上付近から宮城 県北部まで追跡され, 鬼首周辺では平泉軽石層 $(\mathrm{HrP}$ : 早田，1989）と呼ばれている. 北上低地带北部の岩手山
東麓から宮城県北部にかけて，これ以外に同様の層相を 示す示標テフラはない.また, H 2 P の下位には厚さ $1 \mathrm{~m}$ 程度の顕著な赤色風化帯がある.

Hn 4 P, Hn 3 P は黄褐色〜肌色を呈し, 胆沢台地の 南部を中心に分布する．胆沢台地に分布する示標テフラ にはきわめて多量の高温型石英が含まれるが，とくに Hn 4 P には数 $\mathrm{mm}$ 大の高温型石英がザラメ状に多量に 含まれ，非常に特異な様相を呈する。 Hn 3 P は石質岩 片の量が多い. H 1 P は Hn $3 \mathrm{P}$ と後述の Hn $2 \mathrm{P}$ との 間に位置し, 褐色・黄褐色一肌色の粗粒軽石を主体とす る，下位の $\mathrm{H} 2 \mathrm{P}$ と類似するが，石質岩片を多量に含 むことから容易に区別できる.

Hn 2 P, Hn 1 P は黄褐色一肌色を呈する。 Hn 2 Pは 胆沢台地の南部を中心に分布するが，Hn１Ｐは北上低 地帯の南部一带にかなり広範に分布する．両者は類似す るが, Hn $2 \mathrm{P}$ の層厚は薄い. Hn $1 \mathrm{P}$ は明瞭に複数の工 ニットに分けられ，中央部のユニットは上下のユニット に比べて細粒な軽石からなる．上部のユニットには数 $\mathrm{mm}$ 大の黒曜石が含まれる。この黑曜石のフィッション トラック年代測定值は $122.9 \pm 15.1 \mathrm{ka}$ である（大上ほ か, 1986).

HWA は数フォールユニットからなる細粒火山咸であ り, Hn $1 \mathrm{P}$ の約 $1 \mathrm{~m}$ 上方に位置する. 色調は白色一肌 色を呈し，全体に粘土化が進んで㧍り，上部には比較的 多量の岩片が含まれる. HWA は, 胆沢台地西部におい 
てのみ分布を確認できる，その上位には厚さ $80 \mathrm{~cm}$ 程 度の顕著な赤色風化款が認められ，焼石岳山麓ではその 中に多量の安山岩質岩片が堆積している.

\section{胆沢火山灰 (IsA : 新称)}

磨き砂状の, 最大層厚 $5 \mathrm{~cm}$ の橙黄色細粒火山灰層で ある。IsAに含まれる火山ガラスは，発泡の良いパミス 型ガラスが主体をなすが，バブルウォール型のガラスも 多い. ガラスの形状は後述の Toya と類似する。しか し，Toya と比較してややガラスは大型であり（0.5 mm 前後: Toya は $0.3 \mathrm{~mm}$ 程度)，バブルウォール型ガラス の量が多い。化学組成の上では, Toya の火山ガラスと ほとんど完全に一致し(Fig. 3), Toya と区別できない. しかし, 火山ガラスの屈折率は 1.493〜1.495 と, Toya のそれより小さい.また，野外での色調が Toyaより 橙味が強いことから，これを Toya とは異なる示標テフ ラであると認定し，IsA と命名する.

なお，WATANABE（1989）はこれを愛宕火山我と呼 び，後述の AtgA を胆沢火山灰と命名した。しかし，本 火山灰の方がより広域に分布する可能性が高く，地形の 編年上の重要性も大きいと考えられる。このため，改め て本火山灭を知名度の高い名称 (胆沢火山兏) に改称す る。

ほとんどの露頭において，HWA 上方の顕著な赤色風 化殼の上方には Toya が堆積しており，IsA を欠く場合 が多い. IsA と他の示標テフラとの関係が確認できるの は, 現在のところ 1 力所（後述の Loc. 15 : Figs. 4, 5，6）のみである. IsA は, Toya 直下の層準に認めら れる広域火山灰であると考えられるが, 検討資料が不足 しているため，今後の調査によってその正確な性状を確 認してゆく必要がある。

\section{Toya（町田ほか, 1987)}

顕著な赤色風化款の上に，つぶれた軽石状の様相を呈 する黄色ガラス質細粒火山灰が点在する. 層厚は $2 \sim 3$ $\mathrm{cm}$ である. 火山ガラス $(0.3 \mathrm{~mm}$ 程度のものが多い) はよく発泡したパミス型ガラスを主体とし，まれにバブ ルウォール型ガラスを含む。このような火山ガラスの形 状および化学組成・屈折率（1.495１.497）加，本細 粒ガラス質火山灰は Toya に対比される (Fig. 3).

すでに述べたように，Toya 直下には化学組成からは 区別できないIsA が認められる，両者の区別は，色調 や火山ガラスの大きさ，バブルウォールの含有率および 屈折率の違いから行っている．两者の関係については， 火山ガラスの屈折率等から検討してゆくことが必要であ る.

\section{On-PmI（小林ほか，1967）}

一部の段丘磎層直上，あるいは Toya 上方に，層厚 2 ３ cm の黄白色細粒火山庅がパッチ状に確認される。 露頭での外観は下位の Toya と似ているが, より白色味 を帯びていることで区別できる，この細粒ガラス質火川 灰中には火山ガラスのほかに細粒な $(0.3 \mathrm{~mm}$ 前後) 黑 雲母と小量のジルコンが含まれている.

火山ガラスは細粒な $(0.3 \mathrm{~mm}$ 前後 $)$ 発泡の良いパミ ス型ガラスからなり，その化学組成は伊那盆地にて採取 した On-PmIの化学組成とほぼ一致する（Fig. 3).た だし，伊那盆地の On-PmI に比べると，この火山ガラ

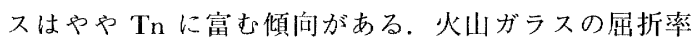
は，1.502〜1.504であり，伊那盆地の On-PmI のそれ と完全に一致する。これらの火山ガラス・含有鉱物の特 性を満たす火山灰は，現在のところ On-PmI 以外には 見あたらない。このような On-PmI に対比される細粒 火山灵は，宮城県北部においても確認されている（早 田，1989；八木・早田，1989）.

\section{愛宕火山灰 (AtgA：新称)}

パミス型火山ガラスと大粒の高温型石英・黑雲母（と

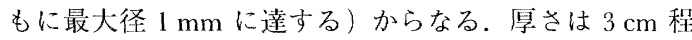
度である，含まれる高温型石英がかなり大きいことか ら，比較的近距離にある火川に由来すると推定される。 なお，本火山灰は，WATANABE（1989）の胆沢火山烐に 相当するが，胆沢火山灰のところで述べた理由から，本 火山灰を愛宕火山在と改称する。

$\operatorname{Atg} \mathrm{A} は$ は，上位の $\mathrm{KtA}$ とわわて近接した層準に存 在し，再者が混在することがある．早田（1989）によれ ば，後述の $\mathrm{KtA}$ 下部がこれとよく似た特徴を示す。し たがって, AtgA ある可能性がある。しかし，露頭によっては（後述の Loc. 5), 層さ $3 \sim 5 \mathrm{~cm}$ 程度の褐色火旧煑を挾んで, $\mathrm{KtA}$ の下位に肉眼で $\operatorname{AtgA} の$ 単層を識別できる。この ため，両者を区別して記載した，本火山炎中の火山ガラ スの屈折率は 1.496〜1.498であり, Toyaのそれと近接 した值を示す.

\section{北原火山灰（KtA：早田，1989）}

On-PmI あるいは Toya の上方に, 緑疢色の砂状の産 状を呈する層厚 2〜4 cm の細粒火山死が堆積してい る.これは, その特異な層相および層準から, 宮城県北 部に分布する KtA（早田，1989）に対比される。KtA 中からは細粒なパミス型ガラスのほかに，黒雲母(いず れも粒径 $0.3 \mathrm{~mm}$ 末満) が検出される. 火山ガラスの屈 折率 $(1.497 \sim 1.500)$ は Toya のそれと類似する. KtA は，和賀川以南の多くの露頭で容易に見いだすことがで 

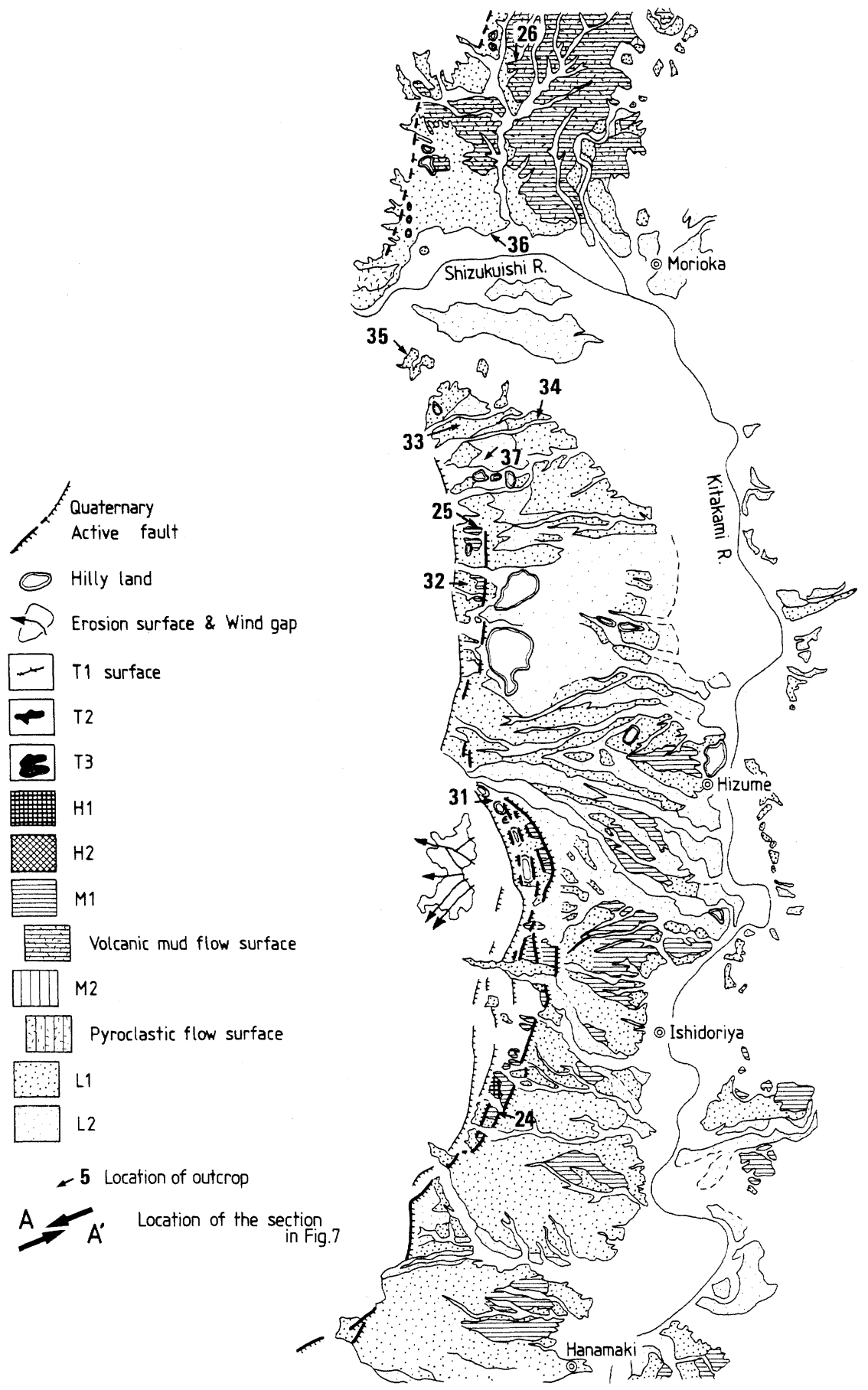

Fig. 4 Fluvial terrace surfaces and erosion surface in the Kitakami Lowland 


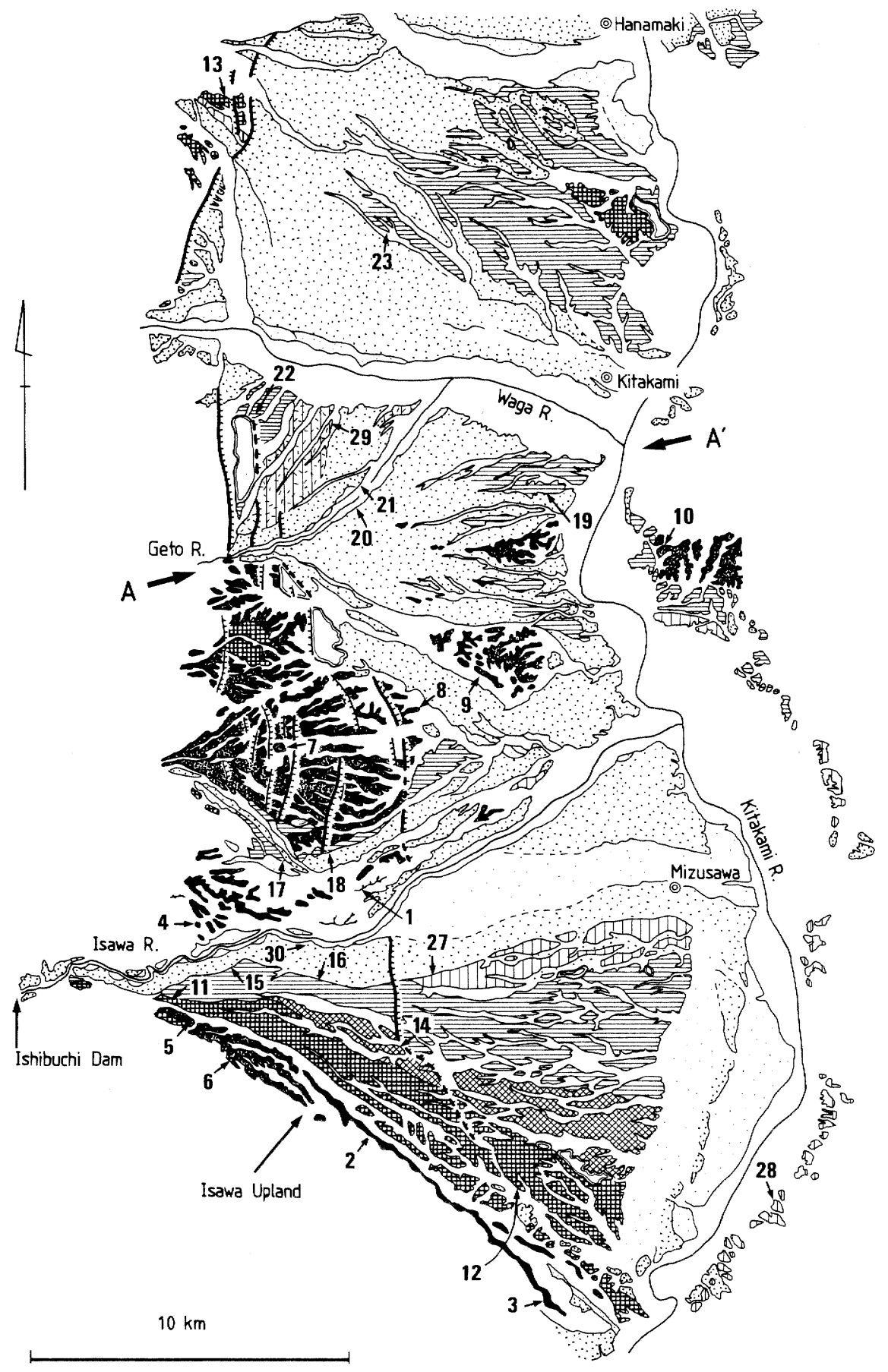




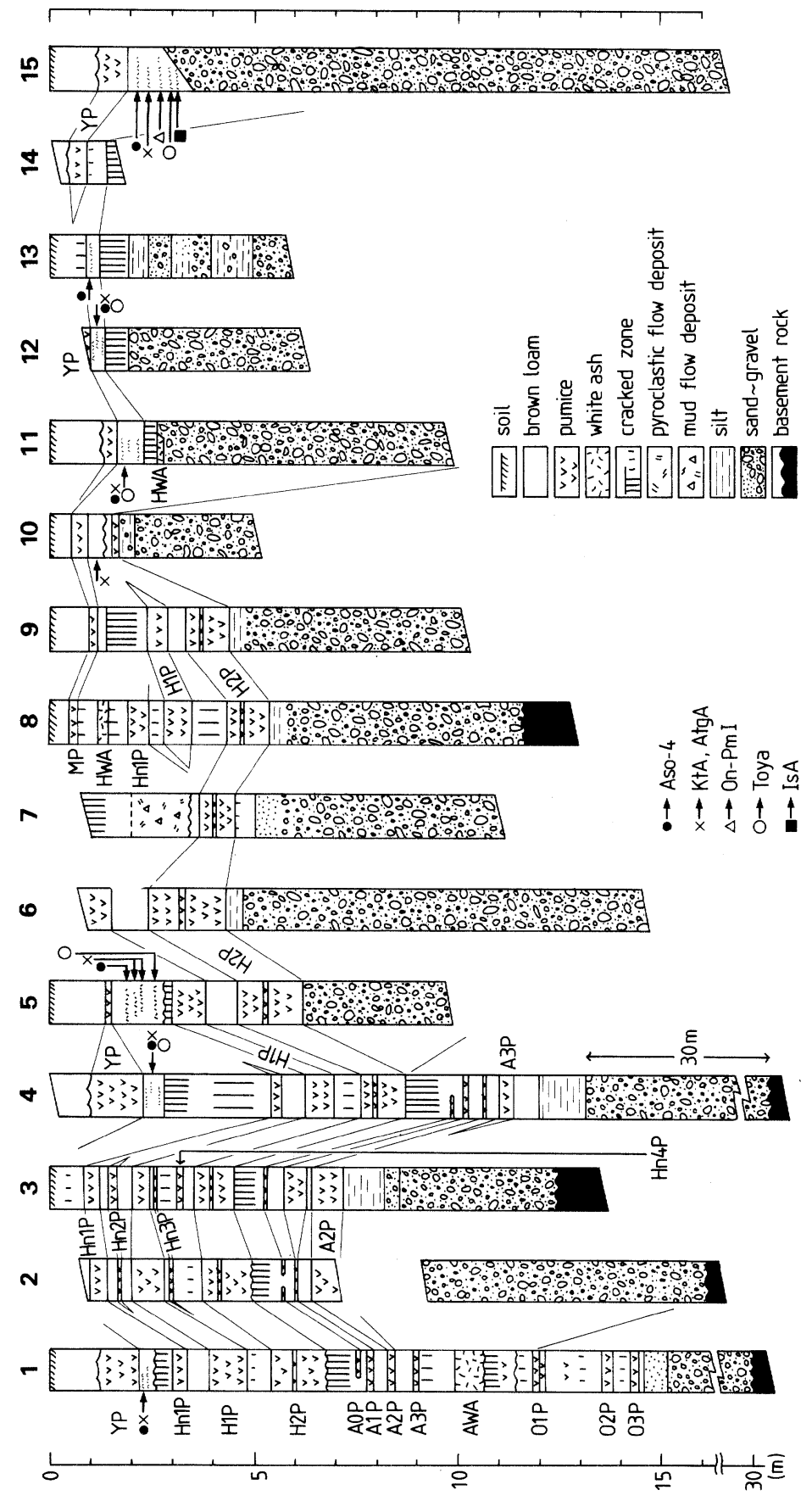




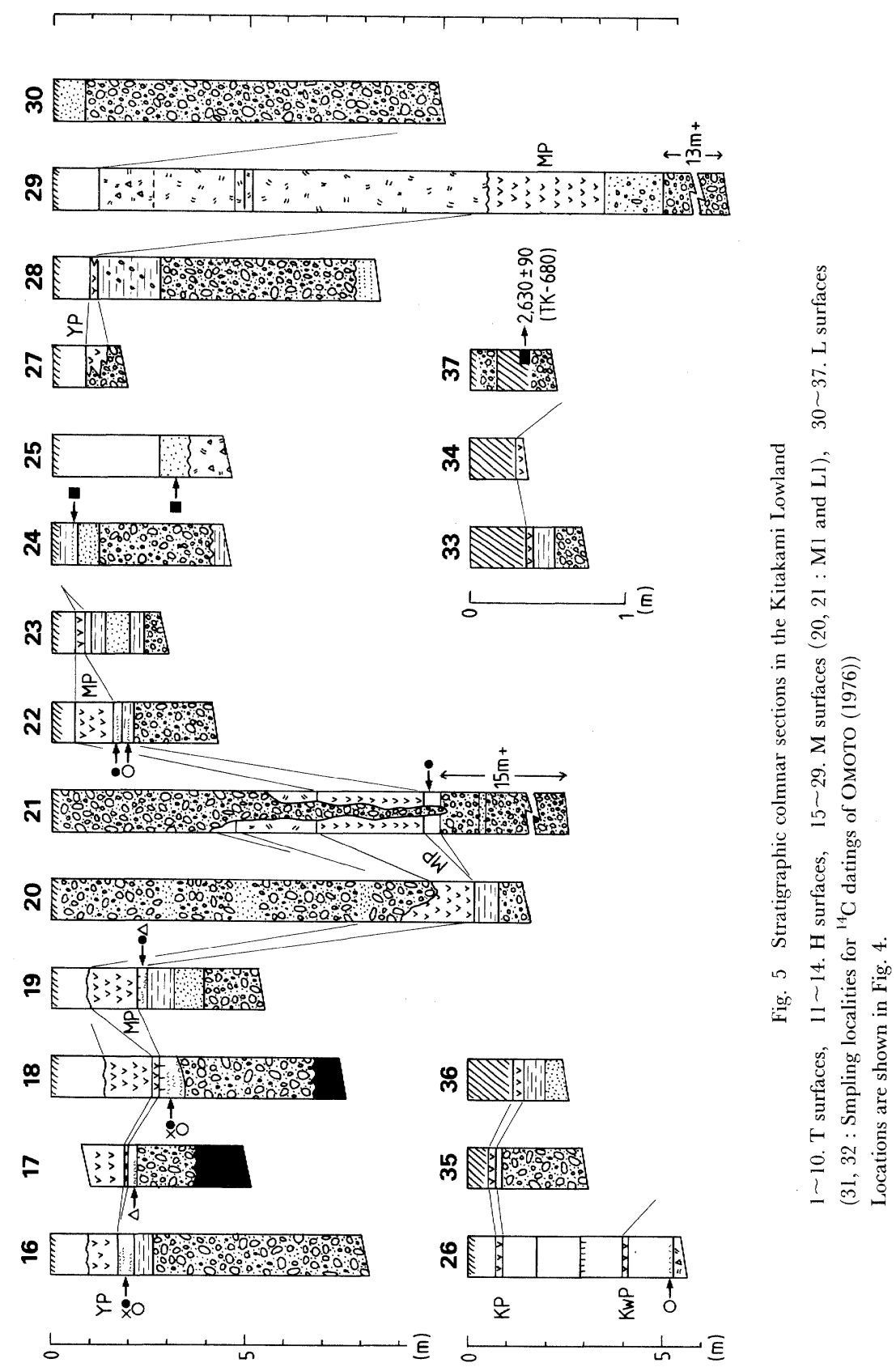


Table 1 Classification and correlation of the fluvial terrace surfaces in the Kitakami Lowland

\begin{tabular}{|c|c|c|c|c|c|}
\hline $\begin{array}{c}\text { Nakagawa et al. } \\
(1963 \mathrm{~b})\end{array}$ & This study & $\begin{array}{c}\text { Okami \& Yoshida } \\
(1984)\end{array}$ & Saito(1978) & \multicolumn{2}{|c|}{$\begin{array}{c}\text { Nakagawa et al. } \\
(1963 \mathrm{~b})\end{array}$} \\
\hline $\begin{array}{l}\text { northern and } \\
\text { central parts }\end{array}$ & whole area & \multicolumn{4}{|c|}{ southern part } \\
\hline $\begin{array}{l}\text { Tonan s. } \\
\text { Iiokano s. }\end{array}$ & L2 s. & $\begin{array}{l}\text { Mizusawa } \\
\text { Lower s. }\end{array}$ & $\begin{array}{l}\text { Mizusawa } \\
\text { Lower s. }\end{array}$ & \multirow{2}{*}{\multicolumn{2}{|c|}{$\begin{array}{c}\text { Kanegasaki s. } \\
\text { Mizusawa s. }\end{array}$}} \\
\hline $\begin{array}{l}\text { Morioka s. } \\
\text { Hanamaki s. }\end{array}$ & L1 s. & $\begin{array}{l}\text { Mizusawa } \\
\text { Upper s. }\end{array}$ & $\begin{array}{l}\text { Mizusawa } \\
\text { Upper s. }\end{array}$ & & \\
\hline & M2 s. & Fukuhara s. & Fukuhara s. & Fukuhara s. & \multirow{4}{*}{ 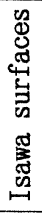 } \\
\hline $\begin{array}{l}\text { Nimaibashi s. } \\
\text { Murasakino s. }\end{array}$ & M1 s. & Horikiri s. & Horikiri s. & Horikiri s. & \\
\hline & $\mathrm{H} 2 \mathrm{~s}$. & Yokomichi s. & Yokomichi s. & Yokomichi s. & \\
\hline & $\mathrm{H} 1 \mathrm{~s}$. & Uenohara s. & Uenohara s. & Uenohara s. & \\
\hline $\begin{array}{c}\text { Ishidoriya s. } \\
\text { Nishine s. }\end{array}$ & T3 s. & Nishine s. & \multirow[t]{2}{*}{ Isshuzaka s. } & \multirow{2}{*}{\multicolumn{2}{|c|}{ Isshuzaka s. }} \\
\hline \multirow[b]{2}{*}{ s. : surface } & T2 s. & Isshuzaka s. & & & \\
\hline & T1 s. & Ohago s. & & & \\
\hline
\end{tabular}

きるため，重要な鍵層である。

\section{Aso-4（町田ほか, 1985)}

$\mathrm{KtA}$ の上方には, 層厚 $3 \mathrm{~cm}$ 程度の橙褐色ガラス質火 山灰が認められる。火山ガラスは，発泡良好で緎細な バブルウォール型ガラス（泡の接合部のみが残った Y 字状のガラス破片が多数含まれる) であり，大きさは 0.3 0.5 mm 程度である。透明無色のガラスが主体であ るが，淡褐色のガラスも含まれる。このような火山ガラ スの特徽および主成分化学組成・屈折率（1.506 1.508）から，この細粒ガラス質火山灰は Aso-4に対比 される. Aso-4 は, 和賀川以南のほとんどの露頭に掞い て認めることができる.

\section{村崎野軽石 $(\mathbf{M P}) \cdot$ 山形軽石 $(\mathbf{Y P})$}

両者は, やや風化の進んだ褐色火山兏層を挾んで, Aso-4の上位に堆積している. 肉眼で確認できる中で は，当地域においては最も新しい示標テフラである，と もに焼石岳起源の粗粒な黄白色パミスからなり, 最大層 厚はそれぞれ $4 \mathrm{~m} \cdot 2 \mathrm{~m}$ に達する．下位の MP は焼石 岳から北東方向に, 上位の YP は東方に分布する（大 上・吉田，1984).Aso-4 と両者の層位関係から, 両者 はほほ同時に噴出したと考えられる．MPには高温型石 英がほとんど含まれないこと, YP と比較して MP の色 調が暗いことから, 両者を区別するのは比較的容易であ る。な抽, 井上・小沼 (1981) は MP と YP の上下関 係について逆の結果を示したが, 本研究は大上・吉田 （1984）の見解を支持する.

\section{3. 段丘面と示標テフラの層位関係および河成段丘面 の対比}

北上低地帯には, 南部ほど古い河成段丘面が分布す る.これらの河成段丘面は，面の連続性・保存度および テフラとの関係から, $\mathrm{T}$ 面群, $\mathrm{H}$ 面群, $\mathrm{M}$ 面群および L 面群に大別される. 従来, 北上低地帯の段丘面には地 域ごとに異なる名称が与えられていたが，同低地帯の全 域にわたる対比がほぼ可能となったので，このように区 分した。なお，河成段丘面の分布はFig. 4 に，主な露頭 柱状図はFig. 5 に, 従来の主な研究における段丘面区分 と本研究での区分との関倸については Table 1 に示す.

\section{1） $\mathbf{T}$ 面群}

$\mathrm{T}$ 面群は開析が進み原面を残さない場合が多く, 和 賀川以南の地域にのみ分布する。 T面群はこれを覆う テフラの層序から,さらに T 1 面〜 T 3 面に細分され る.

T 1 面は胆沢川北岸の標高 $200 ２ 40 \mathrm{~m}$ に分布する が, 開析が進み丘陵化している。面の構成層は数力所で 確認できるが，構成層の層厚およびこれを覆うテフラが 観察できるのはLLc. 1 のみである.ここでは，段丘砂 層は風化の進んだ数〜 $10 \mathrm{~cm}$ 大の亜円碟（主に新第三系 の安山岩・泥岩）からなり，層厚は $15 \mathrm{~m}$ 程度である. 段丘礫層の上位には厚さ $1 \mathrm{~m}$ 弱のフラッドロームが堆 積し，さらにこれをＯ３Ｐ以上のテフラが覆う。

T 2 面も開析が進んでいるが，一部には原面が保存さ れている. A 3 P A 2 P 以上の示標テフラに覆われる. 
胆沢台地（Loc. 2, 3) においては，T 2 面は厚さ $5 \sim 10$ $\mathrm{m}$ の風化の進んだ段丘礫層からなり, $\mathrm{A} 2 \mathrm{P}$ 以上の示標 テフラに覆われる，胆沢川北岸（Loc. 4) では，本面は 主に安山岩類からなり, A 3 P 以上の示標テフラに覆わ れる. T 2 面は, 胆沢台地東端（扇端部）では厚さ数 $\mathrm{m}$ 程度の薄い磁層からなるが, 扇頂部である奥羽山麓では 非常に厚い碟層からなり，Loc. 4 ではその層厚は $30 \mathrm{~m}$ 近くに達する。北上市の南西（Loc. 9 の北方）には, 後述の T 3 面を覆う H 2 P より確実に古いテフラが認 められる。このため，この位置に $\mathrm{T} 2$ 面の分布を推定 した。しかし，面の構成層は確認されて扔らず，詳細に ついては今後の調査が必要である.

T 3 面の原面の保存は比較的良く, 分布も $\mathrm{T} 1$ 面・ T 2 面と比較して広い. 本面は H $2 \mathrm{P} \sim \mathrm{H} 1 \mathrm{P}$ 以上の示標 テフラに覆われる（Loc. 5〜10). 胆沢台地（Loc. 6) に おいては, T 3 面は層厚 $10 \mathrm{~m}$ 以上の礫層からなり, $\mathrm{H}$ $2 \mathrm{P}$ に直接覆われる。段丘砂層は, 最大径 $50 \mathrm{~cm}$ の安山 岩類・花崗岩類の亜円砂からなる，胆沢川北岸の奥羽山 麓においては，厚さ $7 \mathrm{~m}$ 以上の安山岩の亜円础からな る開析扇状地面が分布する ${ }^{3)}$. 段丘砅層は H 2 P ないし H 1 P 以上の示標テフラに覆われている (Loc. 7, 8). T 2 面と同様に, 扇端部では T 3 面構成礫層の層厚は $5 \mathrm{~m}$ 程度と薄くなり, 扇頂部に向かってその層厚は大きくな る.

Loc. 9 周辺では, 一連の開析扇状地面（T 3 面）が若 い扇状地面に分断され，分離丘陵状の形態を示す。ま た, Loc. 9 の東方，北上川左岸には高度 $100 \mathrm{~m}$ 前後に 比較的保存の良い段丘面が分布する（Loc. 10）。この段 丘面は厚さ $4 \mathrm{~m}$ 以上の淘汰の良い細礫層からなる，磁 層中には $5 \mathrm{~cm}$ 大の安山岩の扁平碟やチャートなどの古 期岩帯に由来する砂が多量に含まれ，北上川本流ないし は北上山地から西流する河川が形成したと推定される.

この礫層を橙褐色のテフラが覆うが，風化が著しいた め，テフラの確実な同定はできていない，本研究では層 相をもとにこれを H 2 P に対比し，本段丘面を T 3 面 とした。

\section{2) $\mathrm{H}$ 面群}

H面群はさらに H l 面〜H 2 面に細分され, 原面の 保存も良好である。 H 1 面は, 胆沢台地においては, T 2 面・T 3 面の北縁に沿って分布する. 扇頂部では, 構 成層は数 10〜100 cm 大の亜円磁（安江岩類・花崗㞸

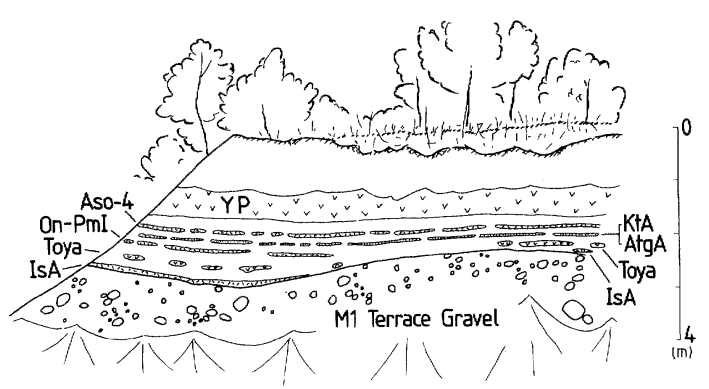

Fig. 6 A sketch showing the outcrop at Loc. 15 (type locality of the M1 surface)

The M1 terrace gravel is overlain by the IsA $\sim$ YP.

類）からなり，H 1 面は Toya 直下の顕著な赤色風化壳 に覆われる（Loc. 11，12）。 Loc. 11 では, 礫層上のフラ ッドローム直上に HWA が介在する．同露頭では段丘 磁層の厚さは $10 \mathrm{~m}$ 以上に達するが, 胆沢台地の東縁部 では H l 面構成碟層の厚さは数 $\mathrm{m}$ 程度しかない.

和賀川以北において，北上低地帯西縁を限る逆断層の 上盤側にわずかに分布する段丘面（Loc. 13 など）も， テフラとの層位関係や堆積物の風化状態から H 1 面に 対比した。しかし, 露頭条件が悪いため, 詳細について は今後の検討を要する.

H 2 面は胆沢台地の H 1 面に沿って分布する. 段丘 面の構成層は，扇端部では $10 〜 20 \mathrm{~cm}$ 大の安山岩を主 体とした亜円碩からなり，Toya 直下の赤色風化殼以上 のテフラに覆われる (Loc. 14). 胆沢台地東縁部では, $\mathrm{H} 2$ 面構成層（厚さは数 $\mathrm{m}$ 以下）は折居層（木野, 1963）を覆っている. 折居層は, チャート磁を多量に含 む細粒・淘汰良好な砂碑層からなり，H 2 面構成層とは 明らかに層相が異なる. 折居層は古期の段丘堆積物の可 能性がある（大上・吉田，1984）.

\section{3) $\mathbf{M}$ 面群}

M 面群は M 1 面と M 2 面に区分される. M 1 面を 覆うテフラのうち, 確実に風成で覆うのは KtA 以上の テフラであるが，風成あるいは水成堆積した On-PmI， Toya あるいは IsA も段丘礫層上に認められる（Loc. 15 〜18). M 1 面は広い範囲に分布し, 胆沢台地から北方 へ北上低地带のほぼ全域に連続する。胆沢台地の Loc. 15 では, IsA がM 1 面構成磁層にアバット状に堆積 し，さらに上位に Toya〜YP の示標テフラが確認でき

3）この付近の T 3 面は多数の開析谷によって分断されているが，開析谷の深さはテフラの厚さに規定されており，あま り深くない。また，この地域には多数の低断層崖が認められ，T 3 面は複雑に変形しているが，より新期の段丘面に は変位を及ぼしていないものが多い(渡辺, 1990). 


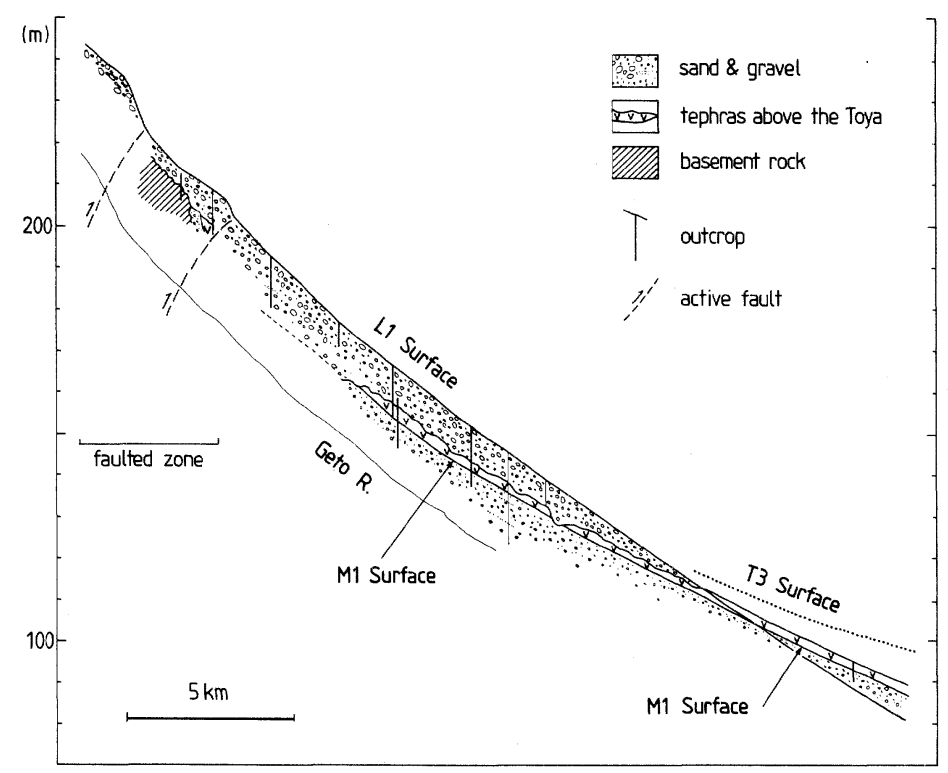

Fig. 7 Topographic and geological section along the line A-A' in Fig. 4

The M1 surface $(80 \sim 90 \mathrm{ka})$ and L1 surface (ca. $20 \mathrm{ka}$ ) converge upon each other.

る（Fig. 6)，Loc. 17 では，段丘磎層の最上部におい て，On-PmI が段丘磁の背後にパッチ状に点在し，Loc． 18 では Toya が鿬層直上に堆積している. 胆沢台地で は，最大径 65〜25 cm の亜円碟からなる段丘礫層によ って構成される.段丘礫層の層厚は，扇端部では数 $\mathrm{m}$ 以下と薄いが，扇頂部では $15 \mathrm{~m}$ 以上に達する.

Loc. 19 と Loc. 23 はいわゆる村崎野面（中川ほか, 1963 b) 上に位置する, これらの露頭では, 段丘面構成 層の上位に $10 \sim 30 \mathrm{~cm}$ 程度の褐色火山灰層を挟んで MP が載り, Loc. 19 においては, 褐色火山灰層中に Aso-4 On-PmI が肉眼で確認できる. 和賀川周辺地域 から北方では, MP 以外の風成堆積物はほとんど認めら れなくなり，細粒ガラス質火山灰の検出は非常に困難に なる．しかし，MP が直接段丘礫層を覆う場合にも，そ の段丘面を切る開析斜面上にも MP が認められること が多い. したがって, 村崎野面の離水と MP の噴出時 期との間には時間間隙があることは間違いない．村崎野 面が胆沢面群 (Table 1) のいずれに対比されるかは, これまでは明らかにされていなかったが，以上に述べた 証拠から, 村崎野面は確実にM 1 面 (堀切面) に対比 される。

なお，中川ほか（1963b)，豊島（1984b）がすでに 指摘しているように，夏油川に沿っては後述の L 1 面 構成層の下位に MP が埋没している（Loc. 20,21）。こ
のうち, Loc. 21 においては, MP とその下位の砂層の 間に厚さ $30 \mathrm{~cm}$ 未満の褐色風化火山灰が認められ, そ こにAso-4 が肉眼で確認された。また，MP上には火 山角礫層（火砕流ないし dry avalanche 堆積物）を挟ん で厚さ 1 2 m の褐色火山在層が堆積している。したが って, Aso-4 降下以前に離水した河成段丘面があり, MP 噴出後かなりの時間をおいて L 1 面を構成する爍 層が累重したと考えられる，テフラとの層序関係から， 下位の碅層は M 1 面構成礫層に対比される。また, 下 流側では M 1 面は L 1 面より高い位置に分布し, その 縦断形は上流側の埋没 M 1 面に滑らかに連続する (Fig. 7). すなわち, 夏油川周辺においては M 1 面と L 1 面は完全に交差している.

夏油川に沿っては同様の露頭が多数あり，それらの観 察によれば,一般に M 1 面構成層より L 1 面構成層の 万が粗粒な碟からなり，M1面構成層の方が厚い. Loc. 20, Loc. 21 付近における鿬層の最大礫径および厚さ は，それぞれ $30 \mathrm{~cm} \cdot 15 \mathrm{~m}$ 以上 $(\mathrm{M} 1$ 面), $50 \mathrm{~cm} \cdot 5$ $10 \mathrm{~m}$ （L 1 面）である.

和賀川南岸の Loc. 22 付近の段丘面は，これまでは後 述の L 1 面に対比されていた. しかし, 今回の調查に よって, 段丘礫層直上の水成堆積火山灭層中に Toya よびAso-4 が堆積していることが確認された. さらに その上位には MP が載る。このため, 高度的にも周囲 
より若干高い部分を M 1 面として表示した.この付近 には火山角砅層が堆積面を形成しているが, 詳細につい ては M 2 面とともに述べる.

花巻以北の奥羽山麓 (Loc. 24, 25) では, 段丘面構成 層中 (その最上部) に, Toya と同一の化学組成をもつ 細粒火山ガラスが多量に含まれる。この火山ガラスは, Toya のそれと比較してやや大型であり，バブルウォー ル型ガラスに富む. したがって, IsA が堆積物中に混入 していると考えられる。この火山がラスが Toya のもの である可能性もあるが, Toya と IsA の層準は近接して いるので，いずれにしてもこれらの段丘面はＭ１面に 対比される.

なお，盛岡周辺には，数枚の泥流堆積物ないし火山角 磁岩からなる広い平坦面が分布する。泥流堆積物の少な くとも一部は Toya に直接覆われ（Loc. 26），その堆積 時期はほぼM 1 面の離水期に近いと考えられる。しか し，大上・土井（1978）も述べているように，明らかに これより古いと考えられる堆積物も分布している．地表 の形態拉よび現在の露頭状態からは，それらを細分して 示すことはできないため, Fig. 4 ではすべてを同一の凡 例で表現した。

M 2 面は胆沢台地の M 1 面東半部に沿って, あるい は北上川左岸の胆沢台地周辺にのみ分布する。胆沢台地 の M 2 面上には出店撓曲線（村田，1939）に沿って変 位が認められ，西側が $10 \mathrm{~m}$ 相対的に隆起している.M 2 面は, 褐色風化火山灰を挟まずに, 直接に整合的に YPに覆われる．YP 上に水成のシルトが堆積している 場合もある。また，Loc. 27 打よび Loc. 28 において は，M 2 面構成層の上部と YP は指交関係にある。す なわち, M 2 面構成層の堆積終了直前に YP が噴出し たと判断される。なお，北上川左岸の北上山麓において は，前述の折居層相当層が $\mathrm{M} 2$ 面構成層の基盤を成 す。本面を構成する磼層の厚さは，確認できる限りにお いては数 $\mathrm{m}$ 程度である.

和賀川南岸 (夏油川北岸)には，MPを多量に取り込 んだ，凝灰質な火山角砂層が分布する。この角磻層は， 一部地域では泥流堆積物の様相を呈するが, Loc. 29 周 辺などにおいては堆積過程において水が関与した痕跡は まったくない，したがって，MP の噴出後に，火砕流な いしは焼石岳の火山体崩壊が発生した可能性が高い。こ の堆積物は M 1 面および L 1 面と近接した高度に堆積 面を形成している。編年上, この堆積面は M 2 面の離 水時期に形成されたと考えるのが妥当であろう。 なお, Loc. 29 では, この火砕流堆積物の下位に MP, M 1 面 構成碟層も確認される。

\section{4) L 面群}

$\mathrm{L}$ 面群は高位のものから L 1 面・L 2 面に区分され る.いずれも開析は進んでいない。これらの段丘面の上 には，北上低地帯北部の岩手山東南麓を除き，テフラは ほとんど載らない。

L 1 面は, 胆沢台地では出店撓曲線に沿って変位を受 け，西側が $5 \mathrm{~m}$ 相対的に隆起している. 段丘面構成層 の厚さは, 撓曲線以東では $8 \mathrm{~m}$, 西で $3 \mathrm{~m}$ といわれてい る(木野，1963)。しかし, 隆起側の Loc. 30 では, 安 山岩類・花崗岩類の亜円砂加なる厚さ $10 \mathrm{~m}$ 以上の段 丘砂層が観察されたすすなわち，砂層の基盤表面にはか なりの起伏があり，これを埋めて L 1 面構成磁層が堆 積している。砂の最大径は $150 \mathrm{~cm}$ に達し，啋層上には 風成堆積物はほとんど認められない。

この扇状地性の段丘面はより北方へ, 北上低地带全域 に連続的に分布し，同低地带内では最も広範に分布する 段斤面となっている．前述したように夏油川流域では， L 1 面構成碩層は M 1 面構成層およびその上のテフラ の上位に累重している (Loc. 20, 21). 花巻周辺などで は，L 1 面はさらに細分することが可能である.

胆沢台地に打ける L 1 面磁層中の木片の ${ }^{14} \mathrm{C}$ 年代は $19.6 \mathrm{ka}$ である。（大上・吉田, 1984)。また, 北上低地 帯中部の日詰西方の Loc. 31, 32 の段丘面構成層中の木 片からは，それぞれ $19 \mathrm{ka} \cdot 26 \mathrm{ka} の{ }^{14} \mathrm{C}$ 年代測定值が 得られている (Омото, 1976). 盛岡周辺では, L 1 面 は KP に覆われる (Loc. 33〜36).

L 2 面は, 胆沢台地周辺と北上低地带の中部一 北部 (石鳥谷の北方) でよく発達している. これ以外に， L 1 面の開析谷中に断片的に分布する段丘面なども L 2 面 に対比した. 北上低地帯北部の Loc. 37 では, L 2 面相 当面の構成層直上の埋没腐植土壤から $2.6 \pm 0.09 \mathrm{ka} の$ 年 代を得た $\left({ }^{14} \mathrm{C}\right.$ 年代：TK-680).

\section{IV. 河成段丘面の編年とこれに関わる問題点}

\section{1. 示標テフラの噴出年代}

Aso-4・On-PmI - Toya の噴出年代は，それぞれのフ イッショントラック年代・ESR 年代，その上下に認め られる示標テフラのフィッショントラック年代，および 海成段丘との関係からまとめられている(町田ほか, 1985，1987; 宮内，1988）。これらの研究によれば, Aso-4 は約 $70 \mathrm{ka} に, O n-P m I$ は約 $80 \mathrm{ka} に$, Toya は $90 \mathrm{ka}$ に噴出したと考えられる.

各広域火山灰間の褐色風化火山灰層の厚さと Aso-4 Toya の噴出年代との関係を Fig. 8 に示した。これによ れば, Toya の堆積期から Aso-4 の堆積期にかけては, 


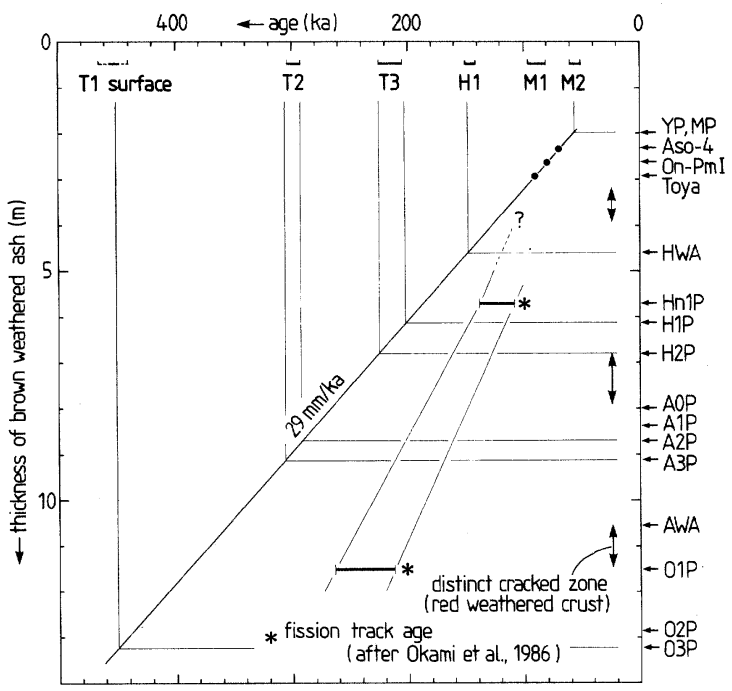

Fig. 8 Estimation of the ages of marker tephras and fluvial terrace surfaces

Estimation was carried out under the assumption that the accumulation rate of brown weathered ash has been constant $(29 \mathrm{~mm} / \mathrm{ka})$.

褐色風化火山灵の堆積速度はほぼ一定 $(29 \mathrm{~mm} / \mathrm{ka})$ で あることがわかる. 褐色風化火山扊が YP あるいは MP の堆積期まで同様の速度で堆積したと仮定すると, YP・MP の推定噴出年代は 50～60 ka となる.

Toya の直下に発達する赤色風化殼はToya の年代か ら $100 \mathrm{ka}$ 前後より古い時代に形成されたことは確実で ある，松井・加藤（1962）によれば, 関東〜東北地方の 古赤色土畩は最終間水期の極相期（substage $5 \mathrm{e}$ ）頃に 形成された場合が多い. Toya と赤色風化款との関係は これと調和するため, この赤色風化殼の層準はほぼ substage $5 \mathrm{e}$ を示すと考えられる.

この赤色風化殼の下方には, フィッショントラック年 代からおよそ $100 〜 140 \mathrm{ka}$ に噴出した（大上ほか, 1986）と推定されている Hn 1 P が堆積している. Toya と Hn $1 \mathrm{P}$ の間には層厚 $3 \mathrm{~m}$ 近くに達する褐色風化火山 灰あるいは赤色風化殼があるため, 両示標テフラの年代 をそのまま適用すると, Hn 1 P 堆積後から Toya 堆積 前の細粒火山灭の堆積速度は Toya 堆積後と比較して相 当大きくなる（小さく見積っても $55 \mathrm{~mm} / \mathrm{ka}$ ).

ところで, O $1 \mathrm{P}$ の噴出年代もフィッショントラック 年代から 215～265 ka とされている（大上ほか, 1986). しかし, 宮城県北部の平泉軽石層（HrP）の上 位の層準からは $210 〜 330 \mathrm{ka}$ のィッショントラック
年代が得られている（鈴木，1988）。 HrP は胆沢台地の $\mathrm{H} 2 \mathrm{P}$ に対比され，その層準はO O P よりもかなり上方 にある. 宮城県北部のテフラに関しては，多数のフィッ ショントラック年代および TL 年代が得られており (輿水, 1983，1986, 1988 ; 鈴木, 1988 ; 市川・平賀, 1988)，テフラ層序と年代值との間にほとんど矛盾を 生じていない.このため, $\mathrm{H} 2 \mathrm{P}$ の噴出年代は若くても $210 \mathrm{ka}$ 前後である可能性がきわめて高い.すなわち, O 1 P のフィッショントラック年代は若過ぎると考えら れる.

ここで, Aso-4〜Toya 間の細粒火山死の堆積速度を 古い方へ外扦してみる (Fig. 8). まず, Toya 下方の赤 色風化殼の層準はほほ $120 \mathrm{ka}$ 前後に対応し, 前述の赤 色風化殼の推定年代と矛盾しない. また, H $2 \mathrm{P}$ の年代 も，>210 ka の条件を満足する.ささらに，H 2 P 直下お よび O $1 \mathrm{P}$ 直上の顕著な赤色風化殼の層準は, それぞ れ 230 270 ka, 350～390 ka の年代に対応し, 深海底コ アの酸素同位体比から認められる温暖期（stage 7 と stage 11）にほほ一致し, 赤色風化殼の形成環境として も問題ない。ここで設定した仮定と調和しないのは $\mathrm{Hn}$ $1 \mathrm{P}$ の年代（約 $180 \mathrm{ka}$ ) であるが, Hn 1 P の年代を 140 $\mathrm{ka}$ 前後と考えれば，それほど大きな矛盾にはならない であろう。

以上の検討から本研究では, 褐色風化火山灰や赤色風 化殼などの細粒火山灰がほぼ一定の速さ $(29 \mathrm{~mm} / \mathrm{ka})$ で堆積してきたと仮定して, 河成段丘面の離水年代を決 める上で必要となる示標テフラの噴出年代を求めた (Fig. 8). 結果は次のとおりである.O $3 \mathrm{P}$ は $450 \mathrm{ka}$ 前 後に, A3P・A2P は $290 \sim 310 \mathrm{ka} に, H 2 \mathrm{P} ・ \mathrm{H} 1 \mathrm{P}$ は 200〜230 ka に, HWA は $150 \mathrm{ka} に$, YP (MP)は 50〜 $60 \mathrm{ka}$ に噴出・堆積したと推定される.

Toya より下位の示標テフラの噴出年代に関する問題 は, 今後の年代資料の蓄積を待って, 改めて検討した い. 以下に, Toya 堆積期前後からの段丘形成を論ず る.

\section{2. 河成段丘面の編年}

第 III 章で述べたように，北上低地帯には，奥羽山脈 から流入する諸河川が形成した多数の扇状地性の河成段 丘面が発達する。本節では, 上で求めたテフラの年代を もとに，これら段丘面の形成時期を推定する.さらに， その多くが堆積面であることを, 主に同低地带南部の胆 沢台地周辺の資料から明らかにする。

\section{1） $\mathbf{T}$ 面群および $\mathbf{H}$ 面群}

$\mathrm{T} 1$ 面は O $3 \mathrm{P}$ 以上のテフラに, T 2 面は A $3 \mathrm{P}$ ない し A 2 P 以上のテフラに, T 3 面は H 2 P ないし H 1 P 
以上のテフラに覆われる (Fig. 2-b). したがって, 先 に求めた各示標テフラの年代から, T 1 面, T 2 面およ び T 3 面は, それぞれ $450 \mathrm{ka}$ 前後, 290〜310 ka, 200〜 $230 \mathrm{ka}$ に離水したと推定される（Fig. 8).

従来, 胆沢台地周辺の河成段丘面は浸蝕面的な特徵を もつとされてきた. 確かに, 扇端部付近では段丘礫層の 層厚は薄く, $5 \mathrm{~m}$ 未満の場合が多い. しかし, Loc. 1 で は, $\mathrm{T} 1$ 面は厚さ $15 \mathrm{~m}$ の㗜層から構成され, T 2 面の 構成層の層厚は優に $20 \mathrm{~m}$ を超える (Loc. 4). T 3 面の 構成础層の層厚も $10 \mathrm{~m}$ 以上に達する場合がある．扇頂 部から扇端にかけて砂層の厚さが異なることは, 磁層の 基底と表面では地形の勾配が違っていることを示す。こ のように, 砂層がかなり厚いことや, 砂層堆積の前後で 縦断形が違っていることは，これら $\mathrm{T}$ 面群が堆積段丘 面としての性格をもつことを示すと考えられる.

H 1 面・H 2 面上には, Toya 直下の赤色風化殸が載 る (Fig. 2-b).このため,これらの河成段丘面は最終 間水期極相期（substage $5 \mathrm{e} ）$ 以前に離水していること は確実である。とくに，H１面の離水時期は HWAに よって示される. HWA の推定年代より，H 1 面は 150 $\mathrm{ka}$ 前後に離水したと考えられる (Fig. 8).この時期は stage 6 の後半に相当する. H 2 面については, 先に述 べた以上にその離水時期を特定することはできない。

胆沢台地においては，H 1 面の構成礫層も, 扇端部付 近では厚さ数 $\mathrm{m}$ を超えることはないが, 扇頂部付近 (Loc. 11) では厚さ $10 \mathrm{~m}$ 以上（磁層の下限は確認でき ない）に達する，本面を構成する礫層も，その前の浸蝕 期に形成された縦断形とは異なる勾配の地形を形成して いる.したがって，本面も堆積面としての性格をもつと 考えられる，H 2 面については，その扇頂部が消失して いるため，十分な検討はできない。確認される限りにお いてはいずれの露頭でも構成礫層は数 $\mathrm{m}$ 以下と薄い.

\section{2）Ｍ面群および L 面群}

M 1 面は確実に KtA 以上のテフラに覆われ, 段丘 䃇層上には On-PmI・Toya が一部水中堆積して載る (Fig. 2-b). また，M 2 面構成層の上部は YP と指交す る場合がある。したがって，M 1 面・M 2 面はそれぞ れ 80〜90 ka・50〜60 ka に離水したと考えられる.

胆沢台地の扇頂部付近では，M 1 面は下限を確認で きない層厚 $15 \mathrm{~m}$ 以上の礫層から構成される。また，夏 油川流域では, 少なくとも厚さ $15 \mathrm{~m}$ に扔よぶ礫層が扇 状地性の M 1 面を構成している (Loc. 21). 胆沢台地 においては，M 1 面の構成礫層の層厚は T 2 面のそれ に次いで厚い。また, 本磁層も胆沢台地東縁部（扇端 部）では薄層となり, 本磁層の堆積の前後では勾配の異
なる地形が形成されており，M1面が堆積面であるの はほほ確実である。

M 2 面はその分布が胆沢台地周辺に限られるととも に, 厚さ $10 \mathrm{~m}$ を超えるような構成礫層は確認されてい ない. 北上山麓における観察によっても, 礫層の厚さは 5〜6 m を超えることはない．M 2 面に関しては情報が ややそしいが，浸蝕面としての性格をもつ場合が多いと 推定される. 夏油川沿いの露頭（Fig. 7) においても M 2 面構成碟層は確認できず, この時代に河谷の埋積が進 行して河床が上昇したかどうか，疑問である.

L 1 面の構成礫層中からは, $19.6 \mathrm{ka}, 19 \mathrm{ka}, 26 \mathrm{ka} の$ ${ }^{14} \mathrm{C}$ 年代が得られている(Омото, 1976 ; 大上・吉田, 1984).この年代は, 北上低地帯北部において L 1 面を 覆う KP の噴出年代 $(13 \sim 16 \mathrm{ka}$ : 遠藤, 1977 ; 井上, 1978 ; 豊島，1984 a）と矛盾しない.すなわち，L 1 面 は約 $20 \mathrm{ka}$ 前後に離水したと推定される，L 1 面は“立 川面”相当面である．Ｌ２面に関しては，年代資料が非 常にそしいが, これを覆う埋没腐植土壤の ${ }^{14} \mathrm{C}$ 年代 $(2.6 \pm 0.09 \mathrm{ka}: \mathrm{TK}-680)$ から, L 2 面の離水年代は 3 $\mathrm{ka}$ 前後としておく.

胆沢台地においては，L 1 面構成層は比較的大きな起 伏を埋めていると考えられる. その最大層厚は少なくと も $10 \mathrm{~m}$ 以上に達する，また，夏油川沿いでは，L 1 面 は厚さ5〜 $10 \mathrm{~m}$ の礫層からなり，この砂層はより勾配 の緩いM 1 面の上に累重し, 以前の地形とは勾配の異 なる地形を新たに作り出している（Fig. 7). したがっ て，L 1 面が堆積段丘面であることは確実である.

L 2 面については詳細は不明であるが，その分布から L 1 面形成後の下刻期に形成された non-cyclic な浸蝕段 丘面が多数を占めると推定される.

以上述べたように, substage $5 \mathrm{e}$ 以降, 胆沢台地およ びその周辺地域においては, 80〜90 ka 以前と $20 \mathrm{ka}$ 前 後に顕著な堆積段丘が形成されている．いずれの時期に おいても, 鿬層の堆積期には以前の地形を埋め, あるい はそれ以前の浸蝕期とは異なる勾配の地形を形成してき ている，一般に，堆積物の層厚が薄いとされてきた胆沢 台地においても，扇頂（上流部）での埋積の進行を明暸 に読み取ることができる。

胆沢台地周辺以北の北上低地帯中部・北部では, M 1 面およびL 1 面はより広範に分布するようになる。こ れらの地域では，段丘硱層の下限や，砂層堆積前後にお ける河川縦断形の違いを露頭で確認することはできな い.しかし, 本低地帯の中部・北部では沈降運動が卓越 し, 粗粒な盆地堆積物の厚さは南部より顕著に厚い（渡 辺，1989）。このため, 低地带中部・北部では，M 1 面 


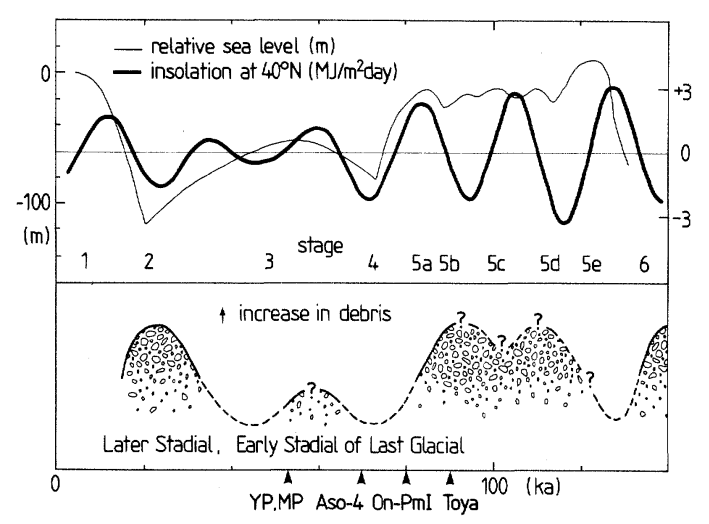

Fig. 9 Secular changes of sea level, insolation and debris supply in the Ou Range

sea level changes: after SHACKLETON and OPdyke (1973), shown by meters below present.

insolation : after BLATTER et al. (1984), shown by deviation of seasonal mean for summer from long term mean $(200,000$ B.P. $\sim 20,000$ A.P. $)$

と L 1 面の構成礫層は, 低地帯南部のそれより厚い䃲 層から構成され，古い礫層に累重すると考えられる。こ のように構成層がその層厚を増すと考えられる地域にお いても，M1面㧍よび L 1 面は比較的広大な扇状地面 をなしており，100 ka および $20 \mathrm{ka}$ 前後の時代には, 北 上低地带およびその周辺地域のほぼ全域において, 河谷 の埋積が進行して河床は上昇したと考えられる.

\section{Stage 5 以降の奥羽山脈からの岩屑供給と森林 限界高度の変遷}

最近十数万年間の北上低地带における段丘形成を特徵 づけるのは, 次の 2 点である。すなわち,

(1) stage 5 中と最終氷期後半に顕著な堆積期があっ たこと,

（2）日高山脈や日本アルプス周辺では顕著な最終水期 前半の堆積期が明瞭でないことである（Fig. 9).

北上低地带における，最終水期前半の段丘形成を示す のはM 2 面であるが, M 2 面の分布は本低地带南部の 胆沢台地周辺に限られ，しかも構成磁層はあまり厚くな い. 北上低地带周辺では, 最終水期前半の埋積に伴う河 床上昇は微弱であり, 隆起地域にのみにその痕跡が残っ ていると考えることができる.

奥羽山脈の山麓部に発達する北上低地帯において堆積 段丘面が形成されたことは, 奥羽山脈からの岩屑供給が 増大したことを示し,これは森林限界の低下あるいは植 生破壊といった現象が進んだこととかなり直接的に対応 するであろう。既に述べてきたように，北上低地带にお
ける最も顕著な堆積段丘の形成は stage 5 といわゆる最 終水期後半に起こり，最終水期前半にはほとんど河谷の 埋積は進まなかった。ししがって, 奥羽山脈の森林限界 は, stage 5 と最終水期後半に最も低下したと考えられ る. 一方, 最終水期前半には森林限界の低下量はかなり 小さかったと考えざるをえない. 当時の森林限界は奥羽 山脈（ほぼ $1,000 \mathrm{~m}$ 程度）より高い位置にあった可能 性もある。

このような奥羽山脈における森林限界高度の定性的な 変遷と従来の研究をもとに, 東日本の山地に扔ける地形 形成環境と植生状態に関する概念図を作成した（Fig. 10). 現在 (Fig. 10, A) および最終水期後半（B）の森 林限界の高度は, 貝塚 (1969), TSUKADA（1984）およ び柳町（1987）に基づきその概要を示した。最終水期前 半 $(\mathrm{C} \sim \mathrm{D})$ の森林限界高度は, 従来の研究では明らか にされていないため, 本研究の結果から, 奥羽山脈には ほとんどかからない程度に定めた，量的な検討は今後の 課題である.また, 現在一最終水期前半の雪線高度につ いては, ONO (1984) および柳町（1987）にしたがっ た. Stage 5 中には, 少なくとも最終水期の前半よりは 低く，後半と同程度かあるいはそれ以上に森林限界が低 下した時期があったと考えられる（Fig. 10，E）。なお， 当時の雪線高度は, 他の時期と比較して最も低い位置に 設定した。 その理由については後述する。

\section{Stage 5 以降の東日本の山地周辺における森林 限界高度と堆積段丘の形成期}

このように奥羽山脈では, stage 5 中（Fig. 10, E）と 最終氷期後半（Fig. 10, B）に森林限界が顕著に低下し たが, 最終水期前半には山地のほとんどの部分が森林限 界より下に位置していた（Fig. 10, C, D ）と推定され る.このような森林限界高度の変遷は, 本調査地域以外 の地域にも当てはまるものであろうか.

まず, stage 5 中の堆積期については, 日高山脈や日 本アルプスにおいてもこれと同様の現象は恋められてい る(伊藤, 1983; 伊藤・正木, 1984; ONO, 1984). 北 上低地带においては，これがより鮮明に現れているので ある.この時代の地形形成については, さらに研究を重 ねる必要があるが, stage 5 中における岩展供給の増大 は普遍的な現象であると予想される。したがって，奥羽 山脈以外でも，この時期に森林限界が低下した可能性は きわめて高い.

次に，最終水期後半の段丘面分布を見ると（日本第四 紀学会編，1987), この時期に形成された扇状地面が日 本列島の各地に発達している. したがって, 最終氷期後 半に岩届供給が増大したことは，疑いはない，ところ 


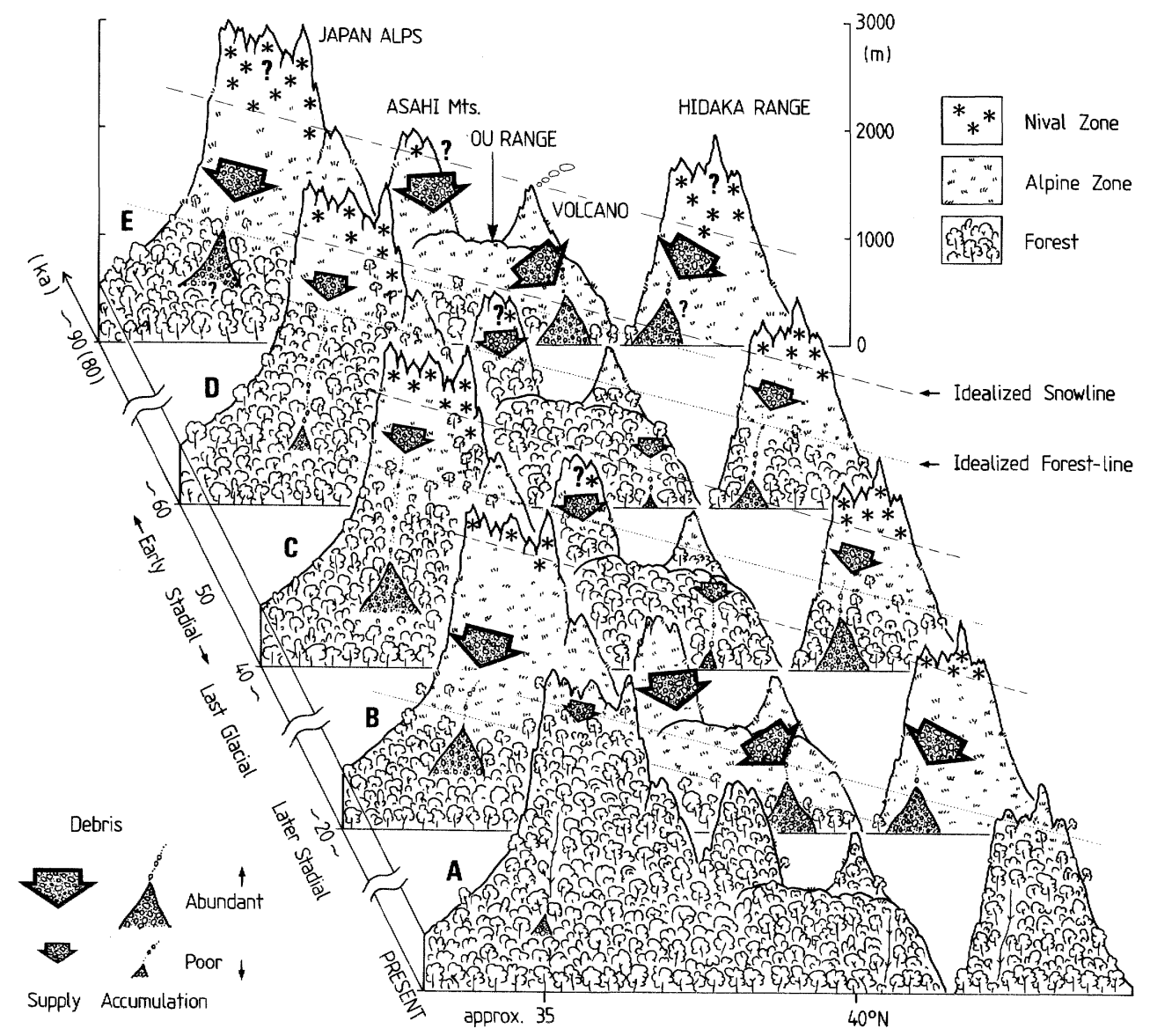

Fig. 10 Proposed model for the morphogenetic and vegetational zones in eastern Japan Environments of the Hidaka Range and the Nihon Apls : simplified and modified from ONO (1984) and YANAIMACHI (1987).

が，日高山脈や日本アルプス周辺では，本調查地域とは 異なり, stage 4 に引き続く最終水期前半において顕著 な堆積段丘が形成されている.すなわち，日高山脈や日 本アルプス周辺での岩屑供給量の変遷は, 本研究で導い た森林限界の低下量の大小とは調和しない。

両山地は, 奥羽山脈と比べて, 緯度的あるいは高度的 にかなり高い山地である。このため, 仮に最終水期前半 の森林限界の低下量が小さくても，これらの山地上部で は最終水期前半にも植生による保護を失った部分がかな り広範に広がったと予想される。このような地域では, 森林限界の低下量以外に寒冷期の継続期間の長短も岩原

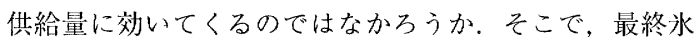
期の前半と後半の継続期間に注目してこの問題を検討し た。
森林限界の低下量は, 最終水期後半の力が大きかった とする.すなわち, 同じ時間内であれば, 前半より後半 における岩屑供給量の方が大きい。一方, 継続期間につ いては, 前者は後者の 2 倍程度の継続期間があったと 考えられる(平川・小野, 1974; 柳町, 1987 など多 数). 継続期間に違いがあったとすれば，単位時間内の 岩屑供給量は最終水期前半の力が小さかったとしても, 長期間にわたって岩屑が供給されうることになる（Fig. $10, \mathrm{D} \rightarrow \mathrm{C}$ の過程). その結果，そこから供給される岩屑 は総量としては大きなものになりうるであろう。このよ うに考えれば，本研究で推定した森林限界高度の変遷 と, 日高山脈や日本アルプスでの地形発達史は矛盾せ ず,これらの地域では, 最終水期後半に匹敵あるいは場 合によってはそれを上回る量の岩屑が最終水期前半に蓄 
積しえたと考えられる，なお，当然のことであるが，最 終水期前半にはほとんど森林限界下にならなかった奥羽 山脈では, 総量をとっても岩屑供給量は少ない.

ところで, 本調査地域における検討によると, 最終水 期の前半と後半では森林限界の低下量には相当の開きが あり，後半の方がより顕著に低下したことが想定され る.したがって，これに基づけば，いくら長期間にわた って日高山脈や日本アルプスの上部が植生による保護を 失っていたとしても, 最終水期後半をはるかに上回る量 の岩屑が最終水期前半の期間に供給された，とは考えに くい. Stage 5 中の堆積物の有無も含めて, 最終水期前 半に堆積したとされてきた堆積物のすべてが, 本当にそ の時期に堆積したものなのかどうか, 再検討する余地も あるように思われる。

以上述べたように，本研究で提示した stage 5 以降の 森林限界高度の变遷（Fig. 10）は, ある程度普遍性をも つと考えられる.これにしたがえば，日高山脈と日本ア ルプスを除く東日本の山地周辺では, stage 5 中と最終 水期後半に最も顕著な岩屑供給があり, 最も顕著な堆積 段斥が形成されたと予想される．最終氷期前半に顕著な 堆積段丘が形成されるためには，日高山脈と日本アルブ スのようにその山地域が緯度的あるいは高度的に高い山 地である必要があると思われる．なお，この時期に東北 地方で顕著な堆積が起こった可能性があるとすれば，山 地の高度から判断して, それは朝日山地周辺であろう (Fig. 10, D, C).

\section{5. 森林限界の低下をもたらした要因}

最終水期の前半より後半の方が森林限界高度が低かっ たことを気温で説明するならば，最終水期後半の方がよ り寒冷な気候の支配下にあったことになろう。叶内 （1988）によれば，福島県南部の奥羽山脈では前半の方 が寒冷であった可能性が高いとされている。しかし，奥 羽山脈の古環境についてはごく少数の資料があるだけで あり，本研究の地形的な証拠もこれを検討する上では重 要な資料となろう.

他の地域の研究結果によれば, 最終水期後半の力が寒 冷で乾燥していた（日高山脈周辺地域: 小野・平川, 1975），山地によってはその状況が異なっていた（中部 日本: 柳町，1987）などとされている. 気候条件につい ては，地域性があることは普通であろう。しかし，一般 的には (広範囲の中で見れば), 最終水期の前半より後 半の方が寒冷であったのではないだろうか. それは, 氷 床の発達程度の違いから容易に想像することができる し，大陸氷中の酸素同位体比（DANSGAARD，1971）によ っても示されている，とすれば，日本においても，一般
には後半の方が寒冷であったと考えられよう。なお，よ り寒冷であるとともに，より乾燥している方が植物の生 育にとっては都合が悪い。したがって, 日高山脈周辺で 明らかにされているように, 最終水期後半により乾燥し ていたとすれば，その影響も森林限界高度の違いに効い ていると考えられる.

Stage 5 中に森林限界が低下して岩屑供給を増大させ た大きな原因は，やはり気候の寒冷化であろう．当時に おける気候の寒冷化については，これを裏付ける研究が 多数ある. BLATTER et al. (1984) は, 天体力学に基づ く日照時間の変化を求め, stage 5 中には, 120 110 ka と $100 \sim 90 \mathrm{ka}$ に顕著な日照時間の減少した期間があっ たことを示している.この 2 つの時期の日照時間は最 終水期中の亜水期（stage 4, stage 2) を凌ぐ程に減少し ている (Fig. 9). 深海底コアの酸素同位体比曲線にも比 較的明瞭な寒冷期（substage $5 \mathrm{~d} \cdot 5 \mathrm{~b}$ ）が現れている (SHACKLETON and OPDYKE, 1973, 1976). 同位体曲線か ら深海水温の影響を除いた大陸水床の成長曲線 (SHACKLETON, 1986) によると,この時期における水河 の拡大は stage 4 や stge 2 と比較して小規模なものであ る.しかし，これは，酸素同位体比に現れるような大規 模な大陸水床の成長には長い時間がかかるのに対し, 寒 冷な substage $5 \mathrm{~d} \cdot 5 \mathrm{~b}$ が短期間しか継続しなかったた めであると考えられる(SAKAGUCHI, 1988)。また，北 海道における花粉分析結果からも, stage 5 中における 寒冷化を支持する資料も提出されている (SAKAGUCHI and OKUMURA, 1986). したがって, stage 5 中のある期 間には, stage 4 扰よび stage 2 に劣ら妨ど，寒冷な気 候条件が卓越していた可能性が極めて高い.

植生破壊につながるもう1つの重要な要因は乾燥化 であるが，現段階ではこれを検討する資料はない。しか し，乾燥化の影響を無視できないとしても， stage 5 中 にかなりの寒冷化があって, それが森林限界高度に大き な影響を与えたと考えざるをえないであろう。ただし， M 1 面の離水時期を直接に示しているのが Toya（90 ka) と On-PmI (80 ka) であるので, substage $5 \mathrm{~d}$ と substage $5 \mathrm{~b}$ のうち, いずれの期間の寒冷化が効いてい るのか，あるいは両者の相乗効果によるものなのか，に ついては確実には判断できない.

このように, 気温的には substage $5 \mathrm{~d} \cdot 5 \mathrm{~b}$ はかなり 寒冷な条件の下にあったと推定され (Fig. 9), 単純に日 射量の減少だけから判断すれば, 最も寒冷な時期は両 substageであったと考えることもできるのである．とこ ろで, substage $5 \mathrm{~d} \cdot 5 \mathrm{~b}$ という時代は，まだ海水準は高 い時代である。したがって，日本海は広く，そこには暖 
流が流れ达む条件が整っており, 大量の水蒸気が供給さ れえたと考えられる.このように考えると，当時は最も 降雪量の多い時期であってしかるべきである. 大陸水河 の蓄積には長期にわたる寒冷期が必要であっても, 山岳 氷河は気候変化にかなり敏感に反応して成長することが できるであろう。すなわち，日本の山岳地带における氷 河の最拡大期は, stage 5 中にあったと考える方が合理 的である。このため, 雪線高度は stage 5 中に最も低か ったと予想して図示した (Fig. 10, E).この点に関して も, 今後さらに検討してゆく必要があるように思われ る.

\section{V. まとめと今後の問題点}

テフロクロノロジーに基づき，北上低地帯に発達する 河成段丘面の編年を行い，奥羽山脈を含む東日本の山地 における岩屑供給量の变遷を検討した。その結果は, 以 下のと抢りである.

1. 本地域の河成段丘面は, T 1 T 3 面, H 1 • H 2 面, M 1・M 2 面, L 1 - L 2 面に区分される. T 1 T 3 面は中期更新世に形成された堆積段丘面である。 H 1 ・ H 2 面は最終間水期極相期直前の水期後半に形成された と考えられる。このうち, H 1 面は顕著な堆積段丘面で ある. M 1 面は stage 5 中の寒冷期に, M 2 面は stage 4 に引き続くいわゆる最終水期前半に形成された。 M 1 面は本低地带のほぼ全域に分布する堆積段丘面である が, M 2 面は浸蝕面である可能性が高い，L1面は最終 水期後半に形成された堆積段丘面である，L 2 面は完新 世に形成されたと考えられるが，詳細は不明である.

2. 後期更新世以降, 本地域においては, stage 5 中と 最終水期後半に顕著な堆積期があり，最終水期前半には 明瞭な堆積期が認められない。このような特徴から, 奥 羽山脈では, stage 5 中か最終水期後半に森林限界が最 も低下したと考えられる．最終水期前半においては，森 林限界低下量は小さく，山地斜面のほとんどは植生によ って保護されていたであろう。

3. 日高山脈や日本アルプス周辺において, 最終氷期 前半に顕著な堆積段丘が形成された理由は，寒冷期の継 続期間が長くこれらの山地が緯度的あるいは高度的に 高い山地であったためであろう．後期更新世以降，日高 山脈や日本アルプスを除く東日本の山地域では, stage 5 中と最終水期後半に最も顕著な堆積段丘面の形成が行わ れたと推定される.

4. 最終水期前半と後半の森林限界の低下量の大小を 気温変化によって説明するなら, 後半の力がより寒冷で あったと結論できる. stage 5 中では, substage $5 \mathrm{~d} \cdot 5 \mathrm{~b}$
の寒冷期が地形形成に深く関与していたと考えられる. この時期の海面高度はほぼ現在と同程度の高度を保って いたことから，当時は最も降雪量の多い時代であり，日 本の山岳水河の最大拡大期はこの時代であった可能性が ある。

朝日山地周辺においては, 最終水期前半の顕著な堆積 期の存在が示唆されている（山中・八木，1986）が, 本 研究で予想したとおり，その可能性は高い。しかし，日 本海側と太平洋側でまったく同じような変化が起こった という保証はなく，確実な年代資料もない。このため, この堆積期が stage 5 中に起こった可能性もある。また 最近，宮城県北部でも広域テフラを用いた地形面の編年 が進みつつある（八木・早田，1989）が, 一般に, 東北 日本においては stage 5〜 stage 3 にかけての河成段丘面 の編年はあまり進んでいない。北上低地帯に扔ける stage 5 以降の地形発達史が, 本地域周辺の東北日本た けに認められる特異な現象であるのか否かを検討するた めには, 東北日本のみならず広範囲の地域で編年学的研 究をさらに蓄積してゆく必要がある. 奥羽山脈のような 高度の低い山地にも明瞭に現れるほどの顕著な寒冷期が stage 5 中にあったとすれば，その影響は日高山脈や日 本アルプスなどの高度の高い山地周辺でも認められるは ずである. また, 最終水期の前半と後半の地形形成環境 の違いに関しては, 奥羽山脈のような高度の低い山地周 辺での研究が重要となろう.

ところで，堆積段斥あるいは扇状地の形成は，気候の 寒冷化だけでなく, 乾燥化, あるいはいかに供給される かという側面からの検討が必要である．M 1 面と L 1 面を比較した場合，明らかにＬ１面の方が粗粒な啋か ら構成されている。このような違いは，両段丘面構成磁 層の堆積時の河川営力が異なっていることを示すと考え られる。しかし，現在のところ過去の流量などに関する 資料はきわめて乏しい，本研究では，主に気温の影響か ら考察を進めたが, 今後はさらに砂径や円摩度, さらに 河川の縦断形などに関する数值的な資料をもとに，段丘 形成を検討してゆく必要があろう。

本研究では，地殻変動の影響はほとんど考虑しなかっ た.WATANABE（1989）によれば, 最近十数万年間の奥 羽山脈主稜線部の隆起速度は $1 \mathrm{~m} / \mathrm{ka}$ に達すると推定さ れている。この隆起速度をそのまま適用すれば, 浸蝕に よる削剥がなかったとして, 最終氷期の後半と前半とで は $30 \mathrm{~m}$ 前後の, 最終水期前半と stage 5 とでは $80 \mathrm{~m}$ 前後の高度差を生ずることになる．この程度の高度差を まったく無視できるとは言い切れないが，おそらく気候 変化による植生带の変動量の方が大きく, 河川への岩屑 
供給という観点からは，こちらの方がより大きな影響を 及ぼすであろう。したがって，第1次近似ではある が，地款変動を無視しても大きな䛊りにならないと考え る.しかし，他地域との比較や，数十万を超えるような タイムスケールの中で地形発達を考える場合などには， 地殼変動によって累積される高度・斜面形の違いなどに も十分な配慮が必要であろう。

謝辞 本研究を行うにあたり，東京大学名誉教授阪口 豊先生 - 東京大学米倉伸之教授 · 大森博雄助教授 - 池田 安隆助手ほかの方々のご指導を頂いた. 同大学院生諸氏 には調査協力と助言を頂いた。とくに，高田将志氏には 火山ガラス化学組成の測定をしていただき, 須貝俊彦氏 には貴重な助言をいただいた。また, 日本大学文理学部 応用地学教室遠藤邦彦教授・宮原智哉氏には, 屈折率測 定器使用に際して快く許可していただいた上, 助言をい ただいた，以上の方々に心から感謝いたします．本研究 には平成 2 年度科学研究費補助金 (奨励研究 (特別研究 員), 課題番号 02952195）の一部を用いた.

なおこの小論を昨春定年退官された阪口 豊先生に 献呈いたします.

\section{引用 文 献}

Blatter, H., Funk, M. and Omura, A. (1984) Atlas of solar climate for the period from 200,000 B. P. to 20,000 years A. P. Zurcher Geogr. Schriften, 10, 162 p.

Chappel.L, L. J. (1974) Geology of coral terraces, Huon Peninsula, New Guinea : A study of Quaternary tectonic movements and sea-level changes. Geol. Soc. Amer. Bull., 85, p. 553-570.

DANSGAARD, W. (1971) Climatic record revealed by the Camp Century ice core. TURekian, K. K.(ed) : Late Cenozoic Glacial Ages. Yale Univ. Press., p. 37-56.

DURY, G. H. (1959) The face of the Earth. Penguin Books, 220 p.

遠藤良二（1977）北上川上流部の化石周水河現象. 日本地 理学会予稿集, no. 12, p. 22-23.

FUJIWARA, K. (1959) Geomorphological development of the Kitakami valley. Sci. Rep. Tohoku Univ., Ser. 7 (Geogr.), 8, p. 8-38.

平川一臣・ 小野有五 (1974) 十勝平野の地形発達史. 地理 学評論, 47, p. 607-632.

市川米太・平賀章三 (1988) 宮城県下の旧石器時代遺跡の 熱ルミネッセンス年代. 日本第四紀学会講演要旨集, no. 18, p. $46-47$.

井上克弘（1978）秋田駒ケ岳火山噴出物の ${ }^{14} \mathrm{C}$ 年代一日本 の第四紀層の ${ }^{14} \mathrm{C}$ 年代 (126)一. 地球科学, 32, p. 221223.

井上克弘・小沼 敦 (1981) 北上川中流における黒沢尻火 山灰の層序・分布と強磁性鉱物の化学組成. 第四紀研
究, 20, p. 1-14.

伊藤真人 (1983) 北アルプス南東部, 蝶ヶ岳付近の水河地 形と堆積段丘. 地理学評論, 56, p. 35-49.

伊藤真人・正木智幸 (1984) 北アルプス, 乳川流域に扮け る更新世の岩屑供給期. 地理学評論, 57 A, p. 282-292.

伊藤真人 ·正木智幸 (1987) 後立山連峰, 鹿島槍ヶ岳, 大 冷沢流域における水河地形と氷河前進期. 地理学評論,

$60 \mathrm{~A}$, p. $567-592$.

貝塚爽平 (1969) 変化する地形一地殻变動と海面変化と気 候変化の中で一. 科学, 39, p. 11-19.

叶内敦子 (1988) 福島県南部・矢の原湿原堆積物の花粉分 析による最終水期の植生変遷. 第四紀研究, 27, p. 177186.

木野義人（1963）5 万分の1の表層地質図「水沢」. 経済企 画庁, $42 \mathrm{p}$.

小林国大 - 清水英樹 - 北沢和男 - 小林武彦 (1967) 御岳第 一浮石層. 地質学雑誌, 73, p. 291-308.

舆水達司（1983）座散乱木遺跡とその周辺のフィッショ ン・トラック年代. 石器文化談話会編「宮城県岩出町座 散乱木遺跡発掘調査報告書 $[I I 」, 136$ p. : p. 97-99.

輿水達司（1986）馬場檀 $\mathrm{A}$ 遺跡の火山灰のフィッション・ トラック年代. 東北歴史資料館・石器文化談話会編「馬 場檀 A 遺跡一前期旧石器時代の研究—」, 220 p. : p. 131-132.

舆水達司（1988）宮城県北部の中・後期更新世テフラのフ イッション・トラック年代. 日本第四紀学会講演要旨 集, no. 18 , p. 54-57.

町田 洋 - 新井房夫 (1979) 大山倉吉軽石層一分布の広域 性と第四紀編年上の意義. 地学雑誌, 88, p. 33-50.

MACHIDA, H. (1980) Tephra and its implications with regard to the Japanese Quaternary period. THE AssociATION OF JAPANESE GEOGRAPHERS (ed.) : Geography of Japan. 440 p., Teikokusyoin : p. 29-53.

町田洋 - 新井房夫 - 小田静夫 - 遠藤邦彦 - 杉原重夫 （1984）テフラと日本考古学. 渡辺直経編「古文化財に関 する保存科学と人文・自然科学」, 8, p. 865-928.

町田 洋 - 新井房夫 - 百瀬 貢 (1985) 阿蘇 4 火山兏一分 布の広域性と後期更新世示標層としての意義一. 火山 (第 2 集), 30, p. 49-70.

町田 洋 - 新井房夫 - 宮内崇裕 - 奥村晃史 (1987) 北日本 在広く㧍扮门洞爺火山灰. 第四紀研究, 26, p. 129-145.

松井 健 - 加藤芳朗 (1962) 日本の赤色土壤の生成時期 · 環境にかんする二, 三の考察. 第四紀研究, 2, p. 161179.

宮城豊彦（1975）北上河谷上流部西縁，志波構造線に沿う 第四紀後期の地款变動. 東北地理, 27, p. 176-186.

宮内崇裕（1988）東北日本北部に打ける後期更新世海成面 の対比と編年. 地理学評論, 61 A, p. 404-422.

水野 裕 (1960) 岩手火山周辺地域の地形発達. 東北地 理, 12, p. 71-76.

村田貞蔵 (1939) 胆沢扇状地の形態学的研究. 地理学評 論, 15, p. 134-147.

中川久夫·石田琢二 · 佐藤二郎 - 松山力 . 七崎 修 (1963 a ) 北上川上流沿岸の第四系扰よび地形一北上川流 域の第四紀地史 (1)-・地質学雑誌, 69, p. 163-171. 
中川久夫・岩井淳一・大池昭二・小野寺信吾 - 森 由級 子・木下 尚・竹内貞子・石田环二 (1963 b) 北上川中 流沿岸の第四系抢よび地形一北上川流域の第四紀地史 (2)一. 地質学雑誌，69，p. 219-227.

NAKATA, T. (1976) Quaternary tectonic movement in Central Tohoku District, northeast Japan. Sci. Rep. Tohoku Univ., Ser. 7 (Geogr.) , 26, p. 213-239.

日本第四紀学会編（1987）日本第四紀地図. 東京大学出版 会, $119 \mathrm{p}$.

大上和良・土井宣夫（1978）北部北上低地帯の鮮新一更 新統の層序について，岩手大学工学部研究報告， 31, p. 63-79.

大上和良・烟村政行・土井宣夫（1980）北部北上低地带の 鮮新一更新統の層序について（その2）。岩手大学了学部 研究報告, 33, p. 53-73.

大上和良・吉田 充 (1984) 北上川中流域, 胆沢羿状地に 扣ける火山灰層序. 岩手大学工学部研究報告, 37, p. 6981 .

大上和良・町田瑞男・吉田 充 (1986) 岩手県, 胆沢䨒状 地域に分布する火山灰のフィッション・トラック年代. 第四紀研究， 24, p. 309-313.

奥村晃史 (1988) 第四紀示標テフラの主成分組成カ夕口 グ. 昭和 $61 \sim 62$ 年度科学研究費補助金研究成果報告書 (総合研究 (A), 研究代表者: 井関弘太郎), p. 159-165.

Омото, K. (1976) Tohoku University radio carbon measurement III. Sci. Rep. Tohoku Univ., Ser. 7 (Geogr.), 26, p. 135-157.

小野有五・平川一臣（1975）ヴュルム氷期における日高山 脈周辺の地形形成環境. 地理学評論, 48, p. 1-26.

ONO, Y. (1984) Last glacial paleoclimate reconstructed from glacial and periglacial landform in Japan. Georgr. Rev. Japan, $\mathbf{5 7}$ B, p. 87-100.

齐藤享治（1978）岩手県胆沢川流域における段丘形成. 地 理学評論, 51, p. 852-863.

SAKAGUChI, Y. and OKumura, K. (1986) Interglacial climates and relic red soils in northern Japan based on pollen records of interglacial deposits in eastern Hokkaido. Bull. Dep. Geogr. Univ. Tokyo, no. 18, p. 29-48.

SAKAGUCHI, Y. (1988) Quaternary glaciation, its appearance and disappearance. Bull. Dep. Geogr. Univ. Tokyo, no. 20, p. 29-41.

Shackleton, N. J. and OPdyke, N. D. (1973) Oxygen isotope and palaeomagnetic stratigraphy Equatorial Pacific core V 28-238: Oxygen isotope temperatures and ice volumes on a $10^{5}$ year and $10^{6}$ year scale. Quaternary Research, 3, p. 39-55.

Shackleton, N. J. and OPDYKE, N. D. (1976) Oxygenisotope and palaeo-magnetic stratigraphy of Pacific core $\mathrm{V}$ 28-239, Late Pleistocene to Latest Pleistocene. Geol. Soc. Amer. Memoir, 194, p. 1121-1132.

Shackleton, N. J. (1987) Oxygen isotopes, ice volume and sea level. Quat. Sci. Rev., 6, p. 183-190.
早田 勉（1989）テフロクロノロジーによる前期旧石器時 代遺物包含層の検討. 第四紀研究, 28, p. 269-282.

鈴木正男（1988）測定結果. 馬場檀 $\mathrm{A}$ 遺跡をめぐる自然科 学的検討会資料. $1 \mathrm{p}$.

田川利三郎・土田定二郎（1939）北上山地の地形学的研 究, 其の 1, 河岸段丘. 斉藤報恩会学術報告, 22, p. 184.

東木龍七（1929）河岸段丘の非対称配置と其の成因. 地理 学評論, 23, p.673-699.

豊島正幸 (1984 a ) 小岩井浮石の降下年代に関する資料, 東北地理, 36, p. 162-163.

豊島正幸（1984 b）胆沢川および夏油川流域の地形. 1984 年度第 31 会ペドロジスト野外見学会資料, p. 2-6.

Toyoshima, M. (1986) The downstream progressing degradation since the Würm stage in the Naruse river basin, northeatern Japan. Sci. Rep. Tohoku Univ., Ser. 7 (Geogr.), 36, p. 114-125.

TsukadA, M. (1983) Vegetation and climate during the Last Glacial maximum in Japan. Quat. Res., 19, p. 212235.

若生達夫（1956）北上川中流域の表層地質による地形面区 分. 東北地理, 9, p. 47-52.

渡辺満久 (1989). 北上低地带の分化様式と断層連動. 地理 学評論, 62 A, p. 734-749.

Watanabe, M. (1989) Complementary distributions of active faults and Quaternary volcanoes, and tectonic movementts, along the volcanic front of the Northeast Japan. Bull. Dep. Geogr. Univ. Tokyo, no. 21, p. 37-74.

渡辺満久（1990）活動時期の違いに基づく活断層詳細図の 表現一テフロクロノロジーからみた北上低地西縁活断層 群 (南半部) の例. 活断層研究, no. 8, p. 71-79.

八木浩司・早田 勉 (1987) 宮城県中・北部に認められる 最終氷期前半の堆積段丘. 日本地理学会予稿集, no. 32, p. 28-29.

八木浩司・早田勉（1989）宮城県中部および北部に分布 する後期更新世広域テフラとその層位. 地学雑誌, $\mathbf{9 8}$, p. 871-885.

山中英二・八木浩司（1987）飯豊・朝日山地周辺の河岸段 丘の形成一とくに低位堆積段丘について. 東北地理, 39, p. 283-301.

柳田 誠・百瀬 貢・大熊良章 (1982) 荒川の河岸段斥. 駒沢大学大学院地理学研究, no. 12, p. 3-13.

柳町 治（1987）氷河・周氷河地形からみた中部日本に扮 ける最終水期の気候・第四紀研究， 25, p. 295-303.

米澤 宏 (1981) 相模川中流域・道志川流域の河岸段兵. 関東の四紀, no. 8, p. 21-32.

吉川虎雄（1961）木曽川の河岸段丘一御岳火山と濃尾平野 との地形発達の関係を中心として一辻村太郎先生古希記 念地理学論文集, p. 70-87.

吉永秀一郎・宮寺正美（1986）荒川中流域に扔ける下位段 丘の形成過程. 第四紀研究, 25, p. 187-201. 
補遺 北上低地带南部の細粒示標テフラ (火山ガラス) 主成分組成（\%)

1 試料あたり 10 粒子以上の平均值 $(\mathrm{M})$ と標準偏差（SD）

\begin{tabular}{c|l|rrrrrrrrrr}
\multicolumn{2}{c}{} & $\mathrm{SiO}_{2}$ & $\mathrm{TiO}_{2}$ & $\mathrm{Al}_{2} \mathrm{O}_{3}$ & $\mathrm{Fe} 0$ & $\mathrm{Mg} 0$ & $\mathrm{MnO}$ & $\mathrm{Ca} 0$ & $\mathrm{~K}_{2} \mathrm{O}$ & $\mathrm{Na}_{2} 0$ & Total \\
\hline Aso-4 & $\mathrm{M}$ & 68.35 & 0.41 & 13.94 & 1.41 & 0.35 & 0.09 & 1.02 & 3.80 & 4.47 & 93.87 \\
& $\mathrm{SD}$ & 1.39 & 0.02 & 0.35 & 0.09 & 0.03 & 0.03 & 0.08 & 0.16 & 0.23 & 1.99 \\
\hline $\mathrm{KtA}$ & $\mathrm{M}$ & 73.27 & 0.11 & 11.43 & 1.18 & 0.09 & 0.07 & 0.93 & 1.61 & 4.00 & 92.75 \\
& $\mathrm{SD}$ & 0.97 & 0.02 & 0.19 & 0.19 & 0.02 & 0.02 & 0.11 & 0.06 & 0.51 & 1.39 \\
\hline AtgA & $\mathrm{M}$ & 73.03 & 0.09 & 11.71 & 0.61 & 0.10 & 0.12 & 0.66 & 3.15 & 3.48 & 92.95 \\
& $\mathrm{SD}$ & 1.20 & 0.02 & 0.20 & 0.05 & 0.01 & 0.03 & 0.04 & 0.11 & 0.29 & 1.48 \\
\hline On- & $\mathrm{M}$ & 69.51 & 0.19 & 12.24 & 1.01 & 0.24 & 0.06 & 1.28 & 3.03 & 2.83 & 90.93 \\
PmI & $\mathrm{SD}$ & 2.13 & 0.04 & 0.77 & 0.24 & 0.05 & 0.02 & 0.06 & 0.18 & 0.41 & 1.59 \\
\hline Toya & $\mathrm{M}$ & 70.26 & 0.05 & 11.34 & 0.88 & 0.04 & 0.09 & 0.37 & 2.24 & 2.90 & 88.17 \\
& $\mathrm{SD}$ & 1.35 & 0.02 & 0.26 & 0.07 & 0.01 & 0.03 & 0.05 & 0.14 & 0.40 & 1.36 \\
\hline IsA & $\mathrm{M}$ & 72.81 & 0.04 & 11.61 & 0.83 & 0.05 & 0.10 & 0.35 & 2.48 & 3.18 & 91.45 \\
& $\mathrm{SD}$ & 0.31 & 0.01 & 0.10 & 0.09 & 0.01 & 0.03 & 0.02 & 0.07 & 0.41 & 0.57
\end{tabular}

